Keila Alessandra BARALDi KNOBEL

\title{
Influência do silêncio e da atenção na percepção auditiva: implicações na compreensão do zumbido
}

Tese apresentada à Faculdade de Medicina da Universidade de São Paulo para obtenção do título de doutor em Ciências.

Área de concentração: Otorrinolaringologia

Orientadora: Profa. Dra. Tanit Ganz Sanchez

São Paulo

2007 


\section{Dados Internacionais de Catalogação na Publicação (CIP)}

Preparada pela Biblioteca da

Faculdade de Medicina da Universidade de São Paulo

Oreprodução autorizada pelo autor

Knobel, Keila Alessandra Baraldi

Influência do silêncio e da atenção na percepção auditiva : implicações na

compreensão do zumbido / Keila Alessandra Baraldi Knobel. -- São Paulo. 2007.

Tese(doutorado)--Faculdade de Medicina da Universidade de São Paulo.

Departamento de Oftalmologia e Otorrinolaringologia.

Área de concentração: Otorrinolaringologia.

Orientadora: Tanit Ganz Sanchez.

Descritores: 1.Percepção auditiva 2.Atenção 3.Zumbido 4.Alucinações

USP/FM/SBD-353/07 
"Eu sei de muito pouco, mas tenho a meu favor tudo o que não sei. E, por ser um campo virgem, está livre de preconceitos. Tudo que não sei é a minha parte maior e melhor. É a minha largueza. É com ela que eu compreenderia tudo. Tudo que eu não sei é que constitui a minha verdade."

(Clarice Lispector)

"In change, I am constant."

(Neeraja Raghavan) 
Para Marcelo, meu Norte, e para Ivan, razão do meu viver. 


\section{Agradecimentos}

Tenho muito a agradecer à Vida, que tem sido tão generosa comigo, e a todas as pessoas queridas que me cercam hoje ou que de alguma maneira contribuíram para que eu pudesse realizar este trabalho que, confesso, me deu muito mais alegrias do que preocupações. Aliás, poucas alegrias se comparam à de fazer o que se gosta...

Agradeço antes de mais nada à minha família, meu maior Bem. Aos meus pais, Geraldo e Angela, pelo amor e apoio incondicionais, pelos exemplos na superação de dificuldades e por sempre acreditarem em mim. À minha irmã, Karen, na qual encontrei, depois de muito tempo, uma verdadeira amiga, e às minhas avós, Terezinha (em memória) e Emilia, mulheres de fibra, verdadeiras guerreiras.

Há oito anos atrás o Marcelo, meu marido, percebeu em mim uma mistura de tédio e de inquietude em relação à minha profissão. E, com sua sensibilidade aguçada, revelou em mim um desejo que eu nem sabia que tinha: você está sentindo falta de estudar. Para cada obstáculo que eu lhe apresentava para voltar a estudar, ele me dava pelo menos duas soluções. Para lhe agradecer o incentivo, a cumplicidade e sua dedicação incansável à nossa relação, tomo emprestadas as palavras de uma música da Badi Assad, "E então, o que seria de mim sem você? Labaredas sem um fogo (...) poço sem os desejos, circo itinerante preso num lugarejo..."

Ao meu sogro, Maurício e à minha sogra, Clara, sou grata pelo carinho e apoio na realização do doutorado. Sobretudo, agradeço ao meu pequeno Ivan que, apesar da pouca idade, foi muito compreensivo nas minhas inúmeras ausências.

Nesta jornada tive a felicidade de ter excelentes professores, a começar pela Dra. Tanit Ganz Sanchez, minha orientadora desde o mestrado. Com ela aprendi que podemos fazer muito mais coisas do que pensamos! Graças à sua visão e experiência

mantivemos o tema deste estudo, que eu estive a ponto de trocar por outro por não acreditar que teria resultados interessantes. Ainda bem que eu soube ouvi-la... Além de ser uma orientadora atenta e disponível, Tanit é uma amiga que não me deixa esquecer dos "mistérios da vida"... Tê-la como orientadora é uma grande honra! 
Não posso deixar de agradecer à minha primeira professora de Audiologia, Profa. Mariene Umeoka Hidaka. Se ela não tivesse me ensinado a ter prazer na Audiologia e não tivesse me incentivado a continuar minha formação na Santa Casa de Misericórdia de São Paulo, meu caminho com certeza teria sido outro. Agradeço, de todo o coração, aos Professores Luiz de Brito, Marcos Vinícius Baldo e Gilberto Fernando Xavier, que inspiraram minha iniciação na neurociência e, à Professora Maria Eugênia Vanzolini, que abriu meus olhos para o mundo da pedagogia no ensino superior. Vocês sempre farão parte da minha história. Às Professoras Eliane Schochat, Roseli Bittar e Andréia Nascimento, meu agradecimento especial pelas sugestões valiosas dadas no exame de qualificação.

Muitos amigos me apoiaram fortemente durante o doutorado e sem eles este trabalho não teria sido possível. Agradeço profundamente à minha amiga Viviane Facchiolli Magaldi, por sua amizade, generosidade e confiança, demonstrados com o empréstimo do analisador de emissão otoacústica, equipamento fundamental para realização deste trabalho e por sua participação na coleta dos dados do projeto piloto. Desde o princípio tive também ao meu lado os amigos Luis Miguel Chiriboga Arteta e Elaine Soares, que sempre tiveram total disposição em me fornecerem os recursos materiais e intelectuais que fossem necessários para a coleta de dados do meu estudo na Maternidade de Campinas. A coleta só não foi feita lá porque o ruído hospitalar, até imperceptível para uma avaliação audiológica comum, se mostrou suficientemente forte para interferir neste estudo, no qual o silêncio tinha que ser o protagonista. Sou grata também à minha secretária, Rose, e ao Rodrigo, pelo agendamento de todas as avaliações.

Agradeço de coração à minha amiga mais talentosa, a artista plástica Lygia Eluf, que me presenteou com o desenho da capa desta tese!

Deixo também minha gratidão às queridas amigas Cláudia Coelho, Gisele Munhóes, companheiras nas dúvidas, nos encontros e nos desencontros, científicos e pessoais, e à também querida Fátima Branco-Barreiro. Foi ela quem, em 1995 despertou minha curiosidade pelo zumbido (pois ela já estudava o assunto) e, em 1997, me convidou para assistir pela primeira vez o seminário de um sujeito de nome difícil, sobre 
Tinnitus Retraining Therapy, durante a Convenção da Academia Americana de Audiologia, em Fort Lauderdale (EUA). A esse "sujeito de nome difícil", Pawell Jastreboff, e à sua esposa e também pesquisadora, Margaret Jastreboff, agradeço por todo o conhecimento dividido comigo em todos os anos que se seguiram àquele primeiro contato, e por me receberem em sua casa para discutirmos os resultados desta pesquisa.

Agradeço aos queridos Ítalo Roberto Torres de Medeiros, Márcia Akemi Kii, Maria Elisabete Bovino Pedalini e Rosa Maria Rodrigues dos Santos, que com suas experiências e "insights" ajudaram-me a pensar e a encontrar soluções para questões desafiadoras.

Pelo auxílio no planejamento do estudo e na análise estatística agradeço à Dra. Maria Cecília Lorenzi e à estatística Sirley Siani Morais.

Agradeço à Maria Marilede Alves e à Maria Márcia Alves, as secretárias da Pósgraduação da Otorrinolaringologia e do Departamento de Otorrinolaringologia, que sempre me atenderam com destreza e simpatia.

Como a finalização deste trabalho desta tese deve obedecer a muitas regras, tive a ajuda inestimável da bibliotecária Marinalva Souza Aragão, a quem também agradeço.

E é claro que eu não teria podido me dedicar tranquilamente ao meu doutorado se não tivesse em casa a Rosa e Rose, que cuidam com carinho da minha casa e do meu filhote! A vocês duas, meu reconhecimento pelo excelente trabalho que realizam!

Sou também muito grata ao Conselho Nacional de Desenvolvimento Científico e Tecnológico $(\mathrm{CNPq})$ pelo apoio financeiro.

Finalmente, agradeço a todos os amigos, familiares, conhecidos e interessados que foram sujeitos desta pesquisa, e sem os quais esta tese simplesmente não existiria! 
Esta tese está de acordo com as seguintes normas, em vigor no momento desta publicação:

Referências: adaptado de International Committee of Medical Journals Editors (Vancouver)

Universidade de São Paulo. Faculdade de Medicina. Serviço de Biblioteca e documentação. Guia de apresentação de dissertações, teses e monografias. Elaborado por Anneliese Carneiro da Cunha, Maria Julia de A. L. Freddi, Maria F. Crestana, Marinalva de Souza Aragão, Suely Campos Cardoso, Valéria Vilhena. 2a ed. São Paulo: Serviço de Biblioteca e Documentação; 2005.

Abreviatura dos títulos dos periódicos de acordo com List of Journals Indexed in Index Medicus.

Ilustração da capa: Lygia Eluf (1986). 


\section{Sumário}

Normas da Otolayngology Head and Neck Surgery (AAO-HNS)

Artigo submetido à AAO-HNS

Carta de aprovação do artigo para publicação

Normas da Ear and Hearing

Artigo submetido à Ear and Hearing

Carta de recebimento do artigo

Lista de Figuras

Lista de Tabelas

Lista de Gráficos

Resumo

Summary

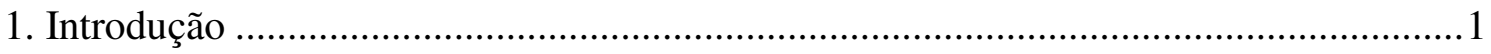

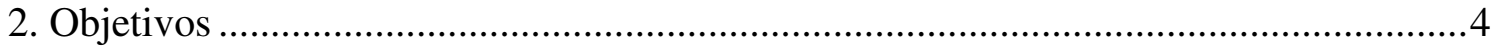

3. Revisão da Literatura ......................................................................................

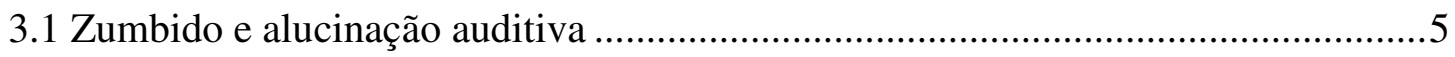

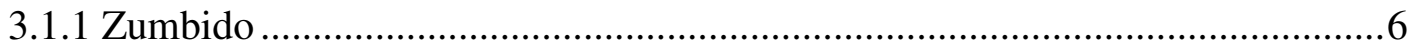

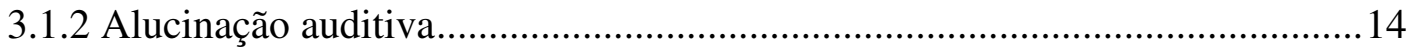

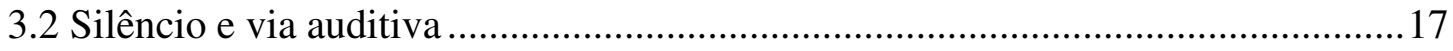

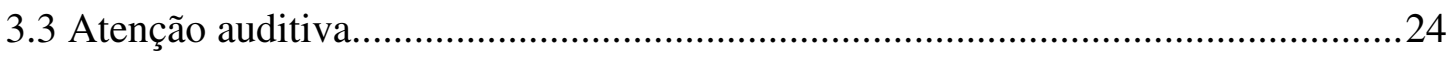

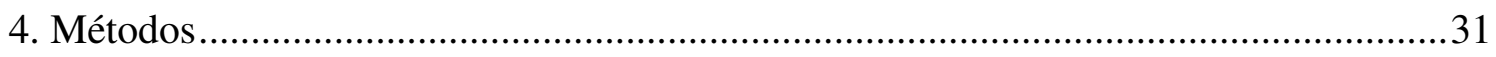

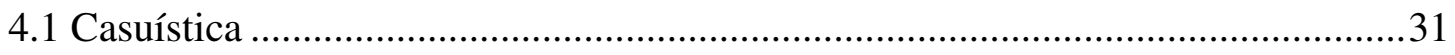

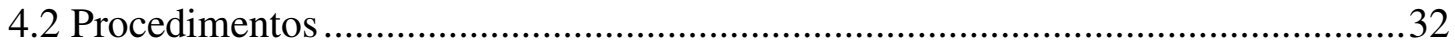

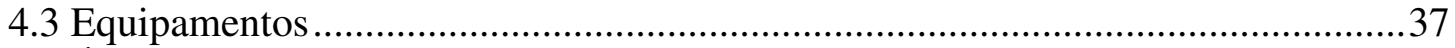

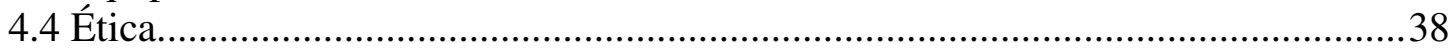

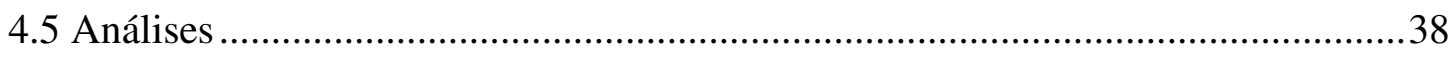

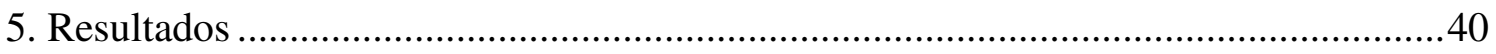

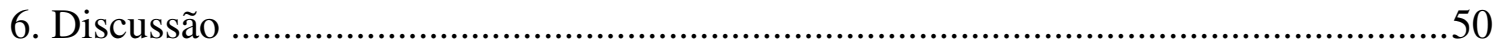

6.1 Comparação entre as percepções auditivas e visuais .........................................51

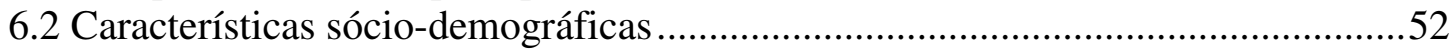

6.3 Comparação das percepções auditivas entre os experimentos .............................53

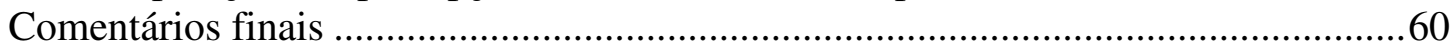

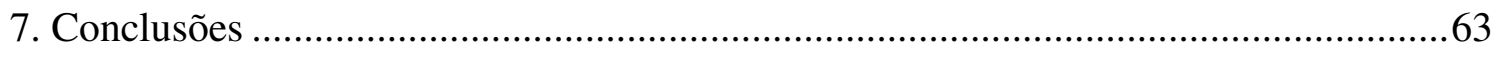

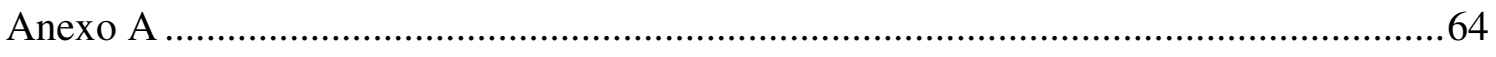

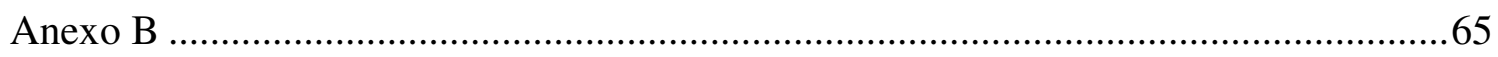

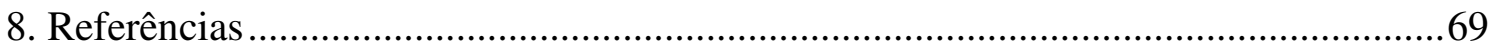




\section{Lista de Figuras}

Figura 1. Ilustração esquemática do modelo de inibição por bandas ___ 9

Figura 2. Torre de Hanói usada no experimento___ 34

Figura 3. Foto de dentro da cabina audiométrica na qual os experimentos foram realizados 


\section{Lista de Tabelas}

Tabela 1 - Distribuição dos sujeitos de acordo com idade e sexo_ 40

Tabela 2 - Distribuição dos sujeitos em função do grau de escolaridade

Tabela 3- Freqüência de percepção auditiva e visual nos experimentos com torre de Hanói, atenção visual e atenção auditiva

Tabela 4 - Diferença entre os testes Hanói, atenção visual e atenção auditiva nas percepções auditiva e visual

Tabela 5 - Diferença entre a ocorrência de percepção auditiva e visual para cada experimento

Tabela 6 - Distribuição da percepção auditiva com atenção auditiva em função da faixa etária dos sujeitos 44

Tabela 7 - Estudo da percepção auditiva nos experimentos com torre de Hanói, com atenção visual e com atenção auditiva segundo variáveis de controle 45

Tabela 8 - Número de percepções auditivas por cada sujeito em cada experimento 46 


\section{Lista de Gráficos}

Gráfico 1 - Freqüência de percepção auditiva e visual nos experimentos com torre de Hanói, com atenção visual e com atenção auditiva 42

Gráfico 3 - Descrição das percepções auditivas predominantes com torre de Hanói 47

Gráfico 4 - Descrição da percepção auditiva com atenção visual 48

Gráfico 5 - Descrição da percepção auditiva com atenção auditiva 48 


\section{Resumo}

Knobel KAB. Influência do silêncio e da atenção na percepção auditiva: implicações na compreensão do zumbido [tese]. São Paulo: Faculdade de Medicina, Universidade de São Paulo; 2007. 81p.

OBJETIVOS: Estudar o efeito da atenção e do silêncio sustentado no aparecimento de percepções auditivas fantasma em adultos normo-ouvintes e a relação com características sócio-demográficas. MÉTODOS: Dentro de uma cabina acústica, 66 voluntários (18 a 65 anos, média etária 37,3 anos) realizaram três experimentos de cinco minutos cada, apresentados consecutivamente e em ordem aleatória. Dois desviavam a atenção do sistema auditivo (Hanói - H e Atenção Visual - AV) e outro a direcionava para ele (Atenção Auditiva - AA). Os sujeitos foram questionados sobre suas percepções auditivas e visuais. Em nenhum momento foram apresentados quaisquer sons ou mudanças na iluminação. RESULTADOS: $19,7 \%$ dos sujeitos experimentaram alguma percepção auditiva durante o experimento $\mathrm{H}, 68,2 \%$ durante o experimento AV e 68,2\% durante o experimento AA, enquanto percepções visuais foram relatadas por $6,1 \%$, $15,2 \%$ e $4,5 \%$ dos sujeitos para os mesmos três experimentos. A diferença na freqüência de percepções auditivas e visuais foi estatisticamente significativa, assim com a diferença na frequiência de percepções auditivas nos três experimentos. Não houve diferença estatisticamente significativa para o aparecimento de percepções auditivas ou visuais em relação às variáveis estudadas (idade, gênero, nível de instrução, hipertensão arterial, diabetes, história de tontura, história prévia de zumbido ou de exposição a níveis de pressão sonora elevados). Um maior número de percepções auditivas foi referido no experimento AA. Enquanto nos experimentos $\mathrm{H}$ e $\mathrm{AV}$ a maioria das percepções auditivas foi descrita como sons típicos de zumbido (apito, chiado, "hum", som de insetos ou de água corrente), no experimento AA 39,9\% dos sujeitos $(n=26)$ relataram a percepção de sons atípicos, mais compatíveis com vivências alucinatórias que com zumbido.

CONCLUSÕES: Zumbido e alucinação auditiva podem ocorrer na população normal em ambiente silencioso, independente de idade, gênero, nível de instrução, hipertensão arterial, diabetes, história de tontura, zumbido, ou exposição prévia a níveis de pressão sonora elevados. A ativação concomitante da atenção auditiva contribuiu de maneira importante na quantidade e na qualidade das percepções auditivas fantasma.

Descritores: percepção auditiva, atenção, zumbido, alucinações. 


\section{Summary}

Knobel KAB. Influence of silence and auditory attention on auditory perceptions: implications to tinnitus comprehension [thesis]. São Paulo: Faculdade de Medicina, Universidade de São Paulo; 2007. 81p.

OBJECTIVE: To study the effect of attention and sustained silence on the emergence of auditory phantom perception in normal hearing adults and social-demographics relations. METHODS: sitting in a sound booth, 66 volunteers (age range 18-65, mean age 37.3) performed three experiments of five minutes each, consecutively and randomly presented. Two deviated attention from auditory system, called Hanoi $(\mathrm{H})$ and Visual Attention (VA) experiments and one drove attention to the auditory system, called Auditory Attention (AA). After each experiment, subjects were asked about their auditory and visual perception. No sound or light change was given at any moment. RESULTS: $19.7 \%$ of the subjects experienced auditory perceptions during $\mathrm{H}, 45.5 \%$ during VA and $68.2 \%$ during AA, while visual perceptions were experienced by $6.1 \%$, $15.2 \%$ and $4.5 \%$ of the subjects for the same three experiments. The frequency of auditory and visual perception was statistically different, as well as the frequency of auditory perception among experiments. No significant differences for auditory perceptions emergence for studied variables were found (age, gender, instructional level, hypertension, diabetes, history of dizziness, history of tinnitus, previous exposure to high sound pressure levels). A higher prevalence of auditory perceptions was found on AA experiment. While on $\mathrm{H}$ and VA experiments most of the auditory perceptions were described as typical tinnitus sounds (whistle, buzzing, hum, insects and running water), on AA experiment $39,9 \%$ of the subjects $(n=26)$ experienced non-typical tinnitus sounds, closer to hallucinatory experiences than to tinnitus. CONCLUSION: Tinnitus and auditory hallucination may occur in a non-clinical population in a silent environment, with no influences from age, gender, instructional level, hypertension, diabetes, history of dizziness, history of tinnitus, previous exposure to high sound pressure levels. Concomitant auditory attention seems to play an important role on the emergence of tinnitus.

Descriptors: auditory perception, attention, tinnitus, hallucinations. 


\section{1}

\section{Introdução}

O sistema nervoso é constantemente bombardeado por inúmeras informações provenientes do próprio organismo e do ambiente. A percepção desses estímulos envolve a integração dinâmica de aspectos externos, dependentes do realce ou da "novidade" do estímulo (processos "bottom-up”), e de aspectos internos, resultantes da integração de decisões internas que direcionam os órgãos sensoriais para determinados estímulos do ambiente (processos “top-down”). As modulações “top-down” referem-se à atenção, expectativa, experiência prévia, antecipação, entre outros. Permitem que o estímulo mais relevante de um determinado momento seja processado de modo mais intenso pelo sistema nervoso, enquanto os demais estímulos são processados de modo atenuado. Diversos estudos recentes têm mostrado que mesmo no silêncio pode haver ativação do córtex auditivo por ativação "top-down" [1-3] e até mesmo a partir de estimulação visual $[4,5]$. 
É interessante notar que a relação sinal-ruído é tão importante quanto a atenção dada ao estímulo. Ruído é "toda fonte de erro, distúrbio ou deformação de fidelidade na transmissão de uma mensagem” [6]. Portanto, qualquer estímulo, acústico ou não, que interfira negativamente na percepção do estímulo-alvo, pode ser considerado ruído. Já a definição de silêncio é "ausência de ruído". Entretanto, é praticamente impossível não haver algum tipo de ruído à nossa volta. O próprio organismo é ruidoso. Mesmo câmaras anecóicas, que têm o menor nível de reverberação possível, não são totalmente à prova de sons. O silêncio verdadeiro só existe no vácuo, onde não há vida nem som.

Quando as pessoas mencionam o silêncio, geralmente se referem à presença de sons muito suaves da natureza, como a brisa nas árvores, a água correndo em um rio ou pássaros cantando ao longe. Paradoxalmente, em algumas situações de risco ou de espera, o silêncio parece aumentar a ansiedade das pessoas. Talvez por isso muitas prefiram ligar o rádio ou a televisão enquanto estão sós em casa.

Pessoas com zumbido referem maior percepção e incômodo quando se deitam para dormir, provavelmente em decorrência do relativo silêncio da noite, que favorece a percepção da atividade elétrica correspondente ao zumbido.

O zumbido, uma percepção auditiva fantasma, deixou de ser considerado exclusivamente sinal de patologia da via auditiva desde que Heller e Bergman sugeriram, em 1953 [7], que 94\% dos indivíduos sem queixas auditivas referiam ter zumbido quando ficavam por 5 minutos em uma câmara silenciosa. Apesar do forte impacto desse estudo até os dias de hoje, a pesquisa original apresenta falhas metodológicas e foi parcialmente replicada apenas duas vezes [8, 9]. Entretanto, também nesses estudos os sujeitos acreditavam que poderiam ouvir algum tipo de som enquanto 
estavam na cabina acústica e, portanto, direcionaram sua atenção para a via auditiva, o que pode ter superestimado os resultados.

Esta pesquisa avalia a hipótese de que indivíduos sem queixas ou alterações auditivas podem ter percepções auditivas fantasma em situações de atenção auditiva em ambientes silenciosos. Além de encontrarmos evidências de zumbido sub-clínico em uma parcela da amostra estudada, o relato de outras percepções auditivas não-verbais (riso de criança, pássaros, som de passos, música, etc.) nos impele a analisar as relações entre o sistema auditivo, os mecanismos de atenção e os mecanismos de geração e percepção de zumbido e de alucinações auditivas.

Acreditamos que este estudo trará uma nova visão a respeito da geração e da percepção desses sintomas, capaz de interferir na abordagem terapêutica da população atendida na clínica. 


\section{Objetivos}

\section{Objetivo geral}

- Avaliar a influência do silêncio e da atenção auditiva na percepção auditiva fantasma em indivíduos com limiares audiométricos normais e sem zumbido.

Objetivos específicos

- Avaliar a freqüência de percepções auditivas fantasma no silêncio sem atenção seletiva para a via auditiva.

- Avaliar a freqüência de percepções auditivas fantasma no silêncio com atenção seletiva para a via auditiva.

- Estudar as características sócio-demográficas associadas à percepção auditiva fantasma no silêncio. 


\section{3}

\section{Revisão da Literatura}

Neste capítulo, optamos por apresentar os trabalhos mais relevantes, completos ou didáticos de maneira a facilitar a leitura e compreensão, sem restringi-los à ordem cronológica. Introduziremos alguns conceitos que serão freqüentemente abordados ao longo do estudo, como zumbido em sujeitos com limiares auditivos normais, pseudoalucinação auditiva, os efeitos do silêncio na via auditiva e a influência da atenção na percepção auditiva e na percepção do zumbido. Embora este estudo trate dos efeitos de um breve período de silêncio sobre a via auditiva normal, citaremos estudos sobre o efeito da privação sensorial no sistema nervoso auditivo central (SNAC) por lesão auditiva aguda e crônica, que podem lançar idéias sobre mecanismos de funcionamento desta via na ausência de estimulação auditiva.

\subsection{Zumbido e alucinação auditiva}

Qualquer percepção sonora que não corresponda a um som externo pode ser chamada de zumbido [10]. Embora a mesma definição possa ser aplicada para as 
alucinações auditivas [11-13], esses dois sintomas têm causas e conteúdo sonoro diferentes e devem ser distinguidos, mesmo quando ocorrem juntos no mesmo paciente [11]. Além de investigação psiquiátrica e otológica completa, Johns et al. [13] sugeriram uma observação prática para auxiliar na diferenciação entre o zumbido e a alucinação auditiva: o zumbido genuíno fica mais perceptível quando o paciente cobre as orelhas com as mãos em concha, ao passo que a manobra não tem nenhum efeito sobre a clareza da alucinação auditiva. Como cerca de 65 a $80 \%$ dos pacientes com zumbidos observam alteração de intensidade, freqüência ou localização do mesmo quando executam modulações somáticas $[14,15]$, a avaliação do efeito das manobras somáticas também pode ser útil na diferenciação entre zumbido e alucinação auditiva [11].

A seguir apresentamos os conceitos vigentes sobre zumbido e alucinação auditiva.

\subsubsection{Zumbido}

O zumbido é comumente descrito pelos pacientes como sons simples (apitos, "hum”, chiados, som de cigarra) únicos ou múltiplos, contínuos ou pulsáteis, percebidos em uma orelha, nas duas orelhas ou na cabeça [16-19]. Geralmente está associado a trauma acústico, doenças otológicas, traumas de cabeça e pescoço, alterações cardiovasculares, doenças metabólicas, neurológicas, psiquiátricas, fatores odontológicos, efeitos colaterais de drogas ototóxicas, abuso de cafeína, nicotina e álcool $[1,9,11-16]$ e é fortemente associado com perda auditiva, uma vez que $78 \%$ a 90\% dos pacientes com zumbido apresentam alteração nos limiares audiométricos [17, 20-25].

O nervo auditivo tem, como qualquer outro nervo, uma atividade espontânea, também chamada de espectro médio de atividade eletrofisiológica coclear ou espectro de 
ruído neural de fundo. Mudanças na atividade espontânea do nervo auditivo indicam mudança na sensação auditiva. Quando esta mudança não corresponde a um estímulo acústico real, o córtex auditivo a interpreta como zumbido.

A atividade neuronal relacionada ao zumbido pode ser o resultado de mecanismos compensatórios que ocorrem na cóclea e/ou nas vias auditivas centrais, geralmente para minimizar as disfunções periféricas [26]. As disfunções periféricas descritas por Jastreboff [26] são: dano desproporcional entre células ciliadas internas e externas, alterações da homeostase do cálcio na função coclear, ativação heterogênea do sistema eferente e hiperatividade das vias auditivas.

Eggermont [10] sugeriu que o zumbido seria decorrente de qualquer mudança na sincronia neural ou nos padrões de descarga elétrica da atividade neural espontânea das vias auditivas. $\mathrm{O}$ aumento da atividade elétrica seria resultado de disfunções que levam à maior entrada de cálcio nas fibras do nervo auditivo, com conseqüente aumento na liberação de neurotransmissores. Assim, picos de atividade elétrica do nervo auditivo, semelhantes aos que ocorrem quando há exposição a sons tonais reais, poderiam ser percebidos como zumbido. Segundo o autor, uma lesão permanente em qualquer ponto da via auditiva pode levar à geração permanente de zumbido, mesmo em indivíduos com lesões auditivas mínimas que apresentam limiares audiométricos normais. O autor enfatiza também que mesmo lesões periféricas geram reorganizações na via auditiva central e que, portanto, não seria possível distinguir zumbidos periféricos de centrais.

Como será exposto a seguir, muitos estudos experimentais parecem corroborar com a teoria de Eggermont [22-28]. 
Wang et al. [27] mostraram que o limiar da frequiência característica e as curvas de frequiências dos neurônios do colículo inferior de cobaias podem ser alteradas mesmo após uma exposição curta a sons intensos (16 kHz a 107 dB NPS por 20 minutos). Houve aumento das respostas neurais do colículo inferior e aparecimento de respostas em frequiências que não faziam parte da curva de sintonia desses neurônios. Eles hipotetizaram que tais alterações poderiam resultar em aumento de atividade espontânea e, assim, se relaciona diretamente com a geração de zumbido pós-trauma acústico.

Em um estudo semelhante, Salvi et al. [28] avaliaram as conseqüências da exposição a sons intensos no núcleo coclear dorsal (NCD) e mostraram que os neurônios com zonas excitatórias estreitas (que respondem a poucas freqüências) tiveram as mesmas mudanças funcionais encontradas no colículo inferior mostradas por Wang et al. [27].

De acordo com Zirpel et al. [29], os eventos inter e intracelulares se alteram quando há perda de elementos pré-sinápticos. Nos neurônios pós-sinápticos pode haver alterações de estrutura, função e metabolismo do mesmo, podendo, muitas vezes, levá-lo à morte neuronal. Desse modo, a lesão coclear pode causar mudanças dramáticas nas respostas excitatórias nos neurônios corticais que servem ao sistema auditivo.

Quando há uma lesão parcial da cóclea, regiões centrais, que antes respondiam pelas regiões cocleares lesadas, passam a ser ocupadas pelas entradas vindas de regiões preservadas da cóclea. Em outras palavras, os mapas tonotópicos de todo o SANC podem ser alterados pela expansão da representação de frequiências cujo limiar de percepção é normal ou melhor que o de freqüências afetadas [30, 31]. 
Outro efeito sofrido no SNAC após uma lesão coclear é o desmascaramento, ou seja, a manifestação de entradas excitatórias que antes eram inibidas [31]. Nesse caso, mesmo uma pequena lesão, permanente ou temporária no órgão receptor, ou uma condição que simule uma perda auditiva, podem levar à perda de inibição imediata ao redor de uma única célula do SNAC (Figura 1) e gerar potenciais elétricos que podem ser percebidos como zumbido [31, 32].
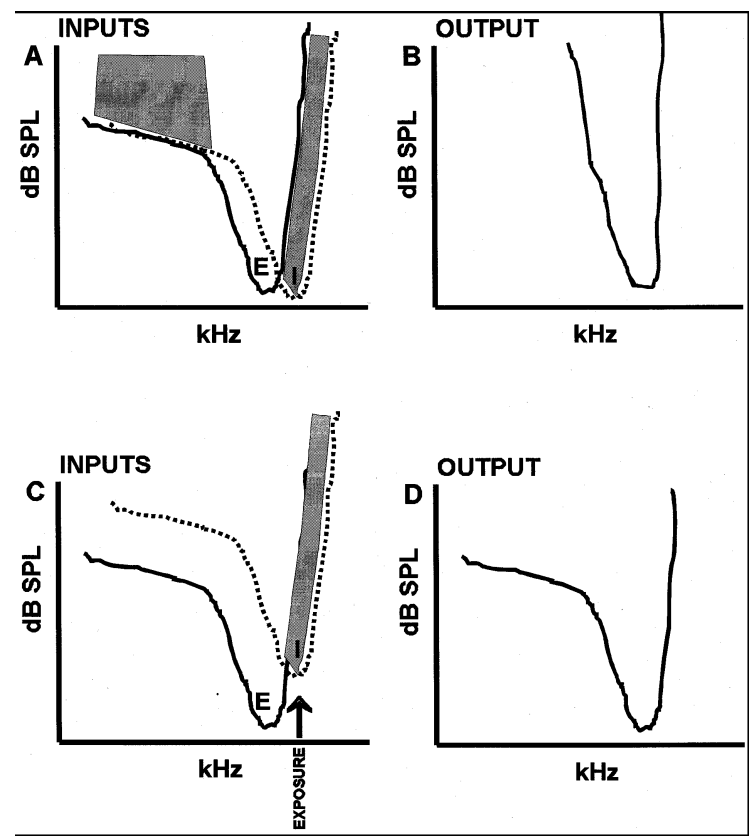

Figura 1. Ilustração esquemática do modelo de inibição por bandas. As figuras de cima mostram dados de uma orelha normal. As figuras de baixo são de uma orelha que sofreu trauma acústico. A: curva de sintonia mostrando a interação entre as entradas (input) excitatórias (linha sólida) e inibitórias (linha pontilhada) de um neurônio normal. A característica de frequiência (CF) da entrada inibitória está localizada em uma freqüência discretamente acima da FC da entrada excitatória. Um neurônio hipotético normal produz uma resposta excitatória (área aberta acima da curva de sintonia excitatória) desde que a entrada excitatória tenha um limiar mais baixo que o limiar de entrada inibitória. As respostas são inibidas, ou mascaradas (área sombreada), se a entrada inibitória tiver um limiar igual ou inferior ao da entrada excitatória. B: A saída (output) excitatória hipotética do neurônio normal em A. C: O mesmo modelo é mostrado, mas o limiar da entrada inibitória é elevado como resultado a uma exposição acústica a um tom que traumatizou a frequiência acima da FC excitatória e próxima à FC inibitória. D: Igual a B, mas com saída do neurônio modificada pelo tom traumatizante. Notar que a saída das respostas excitatórias são expandidas, principalmente nas áreas da curva que respondem às freqüências baixas. (Figura de Salvi et al. [32], com permissão do autor). 
Apesar dos estudos que evidenciam aumento na atividade do sistema auditivo central após deaferentação, existem controvérsias. Tucci et al. [33] realizaram um estudo da atividade neuronal de cobaias (idade de 6 a 8 semanas) com perda auditiva condutiva bilateral por remoção unilateral do martelo e obliteração dos dois meatos acústicos. Compararam a densidade ótica dos núcleos auditivos desses animais com um grupo controle. Para manter o máximo possível a condição de privação sensorial, os animais permaneceram em cabinas acústicas desde a recuperação da cirurgia até o momento de serem sacrificados (48 horas). A atividade neuronal foi medida com a técnica 2deoxiglucose (2-DG) com autorradiografia dos núcleos auditivos do tronco encefálico. A perda condutiva resultou na diminuição da captação da 2-DG no núcleo auditivo, no lemnisco lateral, no núcleo medial do corpo trapezóide, no núcleo ventral do lemnisco lateral e no colículo inferior bilateralmente, o que sugeriu menor atividade metabólica nesses sítios. Os autores consideram que mudanças de inervação eferente em cobaias em diferentes períodos maturacionais poderiam justificar resultados diferentes em experimentos semelhantes em cobaias mais jovens.

Brozoski et al. [34] demonstraram que chinchilas com evidências psicofísicas de zumbido crônico por exposição a tom puro ( $4 \mathrm{KHz}$ a $80 \mathrm{~dB}$ NPS) têm aumento na atividade espontânea e nas respostas evocadas por estímulos em células fusiformes putativas do núcleo coclear dorsal para tons de $1 \mathrm{KHz}$, freqüência do zumbido dos animais. Os pesquisadores inferiram a sensação de frequiência do zumbido das chinchilas por meio de um teste de discriminação de frequiências feito antes e após a exposição ao tom puro, no qual os animais mostraram maior dificuldade para discriminar tons de 1 KHz após a exposição. 
Embora o zumbido seja fortemente relacionado a alterações otológicas, Cacace [35] aloca-o como uma entidade muito mais complexa, que pode envolver interações anormais entre múltiplas modalidades sensoriais, sistemas motores, redes neurocognitivas e vias cerebrais envolvidas no processamento de reações emocionais, já que $10 \%$ da população geral tem zumbido, mas apenas 1 a 3\% relatam incômodo severo com o sintoma [36].

Dois modelos, o 'modelo psicológico' e o 'modelo neurofisiológico de Jastreboff', propõem explicações para os diferentes graus de incômodo da população com zumbido. O 'modelo psicológico' deriva essencialmente do trabalho de Hallam et al. [37], que consideraram os papéis da atenção e dos processos emocionais nos pacientes com zumbido clinicamente significativo e introduziram a habituação como objetivo terapêutico para tratamento desses pacientes. Segundo os autores, a exposição repetida e persistente a altos níveis de estímulo auditivo ou a associação do zumbido a um significado afetivo impedem a habituação ao zumbido. Para eles, os sistemas neurais envolvidos na percepção do zumbido estão ligados ao hipocampo, uma parte do sistema límbico que é a porta de entrada para os centros mediadores de controle emocional e importante componente do sistema de memória. Eles afirmam que a severidade do impacto psicológico do zumbido depende da natureza e extensão das transformações plásticas dentro do sistema auditivo central. Dessa abordagem derivou ainda o uso da terapia cognitiva para o tratamento de pacientes muito incomodados com o zumbido [38].

O 'modelo neurofisiológico de Jastreboff' foi descrito em 1990 [26] e depois adaptado para ser usado como fundamentação da Tinnitus Retraining Therapy [39, 40], 
chamada no Brasil de "Terapia de Habituação do Zumbido" [41]. O modelo sintetiza o conhecimento sobre a via auditiva e a função do sistema nervoso autônomo e do sistema límbico, propondo que a interação dinâmica entre os centros auditivos e não-auditivos do sistema nervoso seja desencadeadora das associações emocionais negativas e das reações de incômodo dos pacientes com zumbido clinicamente significativo. A terapia de habituação do zumbido consiste de dois elementos: (i) orientações, sobre fisiologia da audição e do zumbido, causas de incômodo com o zumbido e funcionamento da terapia e (ii) uso de sons suaves e constantes para diminuir a percepção do zumbido [39, 40].

Estudos eletrofisiológicos e de imagem mostram haver uma relação positiva entre percepção do zumbido e ativação de áreas neurais relacionadas com atenção, emoção e memória.

Jacobson et al. [42] sugeriram que quando o zumbido é relacionado a um perigo, mecanismos de atenção são acionados para perceber o sintoma, o que potencializa os efeitos nociceptivos do zumbido. Eles demonstraram haver antecipação na onda $\mathrm{Nd}$, a onda negativa dos potenciais evocados tardios (considerada um índex eletrofisiológico de atenção auditiva seletiva), em pacientes com zumbido clinicamente significativo.

Lockwood et al. [43] usaram tomografia por emissão de pósitrons (PET) para mapear regiões cerebrais que respondessem a mudanças na sensação de intensidade do zumbido de quatro pacientes que conseguiam modular seu zumbido com movimentos oro-faciais voluntários e compararam-nos a seis controles que faziam movimentos orofaciais enquanto ouviam a tons puros. Foram observadas as seguintes diferenças entre os pacientes com zumbido e os controles: as mudanças na sensação de intensidade do zumbido provocaram mudanças no córtex contralateral à orelha com zumbido, enquanto 
a estimulação unilateral com tons puros gerou ativação bilateral. Para os autores, isso mostrou que a origem do zumbido desses pacientes era retrococlear. Os pacientes mostraram ligações aberrantes entre o sistema auditivo e o sistema límbico, resultado de plasticidade cerebral. Os autores sugeriram que a plasticidade observada tenha sido provocada pelo impacto emocional do sintoma dos pacientes, mas admitem não ter sido possível identificar o quanto essa mudança foi decorrente da perda auditiva, do zumbido ou da combinação entre os dois fatores.

Mirz et al. [44] avaliaram 12 sujeitos com zumbido, também por PET, antes e após a administração de lidocaína endovenosa, que tem um conhecido efeito supressor no zumbido. Os pesquisadores subtraíram as imagens da distribuição do fluxo sanguíneo obtidas com o sujeito com e sem percepção do zumbido para identificar as áreas cerebrais relacionadas à representação do sintoma. Os resultados indicaram que a sensação do zumbido está associada com maior atividade do hemisfério direito, com focos de atividade nas áreas corticais funcionalmente relacionadas com a atenção, emoção e memória (córteces pré-frontal e temporal) e que o zumbido clinicamente significativo está associado a um direcionamento impróprio da atenção, que manteria um estado de alerta sustentado.

Baguley [45] abordou os mecanismos fisiológicos do zumbido sob dois conceitos distintos: o sítio de ignição do zumbido e os mecanismos de promoção do zumbido na via auditiva. Considera que haja casos de sítios de ignição únicos ou múltiplos num mesmo sujeito, por aumento da atividade espontânea do nervo coclear devido a disfunções cocleares ou do nervo coclear, ou ainda por interação entre as vias auditiva e somática. Os mecanismos de promoção do zumbido na via auditiva incluiriam aumento 
de descargas espontâneas, desinibição e reorganização do sistema auditivo central através da neuroplasticidade. Segundo o autor, a distinção entre sítio de ignição do zumbido e mecanismos de promoção do zumbido na via auditiva pode auxiliar na escolha da melhor estratégia terapêutica para o paciente.

Georgiewa et al. [18] realizaram uma revisão crítica da literatura a respeito dos mecanismos envolvidos na geração e na percepção do zumbido e consideraram que a grande variedade de hipóteses e teorias encontradas refletem a heterogeneidade deste sintoma. A partir de resultados de pesquisas de imagem do SNC e dos mecanismos de interações entre as redes neurais relacionadas à atenção, cognição e regulação emocional, os autores propõem um modelo integrativo que considera múltiplos mecanismos simultâneos ou interativos envolvidos na geração periférica e/ou central do zumbido.

\subsubsection{Alucinação auditiva}

Existem três tipos de vivências alucinatórias, cujos conceitos às vezes se confundem: as alucinações verdadeiras, as pseudo-alucinações e as alucinoses [46]. Segundo o Manual de Diagnóstico e Estatística da Associação Norte-Americana de Psiquiatria (DSM-IV) [47], alucinação é uma distorção da percepção sensorial que traz o mesmo senso de realidade de uma percepção verdadeira, mas que ocorre sem a estimulação do órgão sensorial relevante. Nas pseudo-alucinações a crença na realidade do fenômeno é a mesma observada nas alucinações verdadeiras, mas diferenciam-se pela ausência de corporeidade e localização no espaço subjetivo interno, o que as torna mais semelhantes às imagens representativas do que às perceptivas [46]. Já o termo alucinose 
refere-se à percepção de característica alucinatória, mas em que o paciente reconhece aquela experiência perceptiva como um acontecimento patológico [46, 48].

Um outro tipo de erro perceptual é a ilusão auditiva, proveniente de discrepâncias perceptuais que ocorrem a partir de condições idênticas de estimulação, mas no qual parte de um percepto é tomado erroneamente como parte de um outro percepto completo[49]. As ilusões são geradas pelos mesmos mecanismos fisiológicos que produzem a nossa percepção cotidiana [49], e não por uma alteração dos mesmos.

Apesar da distinção entre os termos referentes às alterações sensoperceptivas, esses conceitos não são universais nem usados com uniformidade na literatura. Nesta revisão não serão citados artigos sobre alucinação verdadeira, mas manteremos o termo usado pelos autores.

Um modelo dimensional de classificação, oposto ao sistema tradicional de categorização de sintomas e doenças, sugere a existência de um continuum entre transtornos mentais e a personalidade normal, no qual os transtornos seriam o extremo oposto da normalidade [13]. Assim pensando, não seria surpreendente considerar que alucinações não sejam invariavelmente sinal de doença e que diversos tipos de alucinação possam ocorrer na população normal, como mostraram diversos trabalhos [4, 45-49].

A alucinação auditiva caracteriza-se pela percepção de voz articulada ou de melodias musicais $[11,13]$. Ocorre em uma vasta gama de estados emocionais e orgânicos, incluindo doenças neurológicas degenerativas e acidentes vasculares [50], perdas auditivas, efeitos colaterais de certas drogas [11, 50], efeitos colaterais de radioterapia [51] e em indivíduos saudáveis durante hipnose [1]. 
A alucinação musical é um fenômeno bastante heterogêneo e raro, com cerca de 200 casos relatados na literatura [50], mas não incomum na clínica neurológica e psiquiátrica [12]. Recentemente tem chamado a atenção de otorrinolaringologistas e audiologistas que atendem pacientes com zumbido. De acordo com Fukunishi et al. [50] a prevalência da alucinação auditiva musical em uma amostra de 3.678 pacientes do departamento de psiquiatria de dois hospitais gerais foi de 0,16\% (n=6). Entretanto, um estudo com idosos com perda de audição mostrou prevalência de 2,5\% [52].

Durante as alucinações auditivas verbais e musicais e na imagética (simulação mental de um som) há ativação do córtex auditivo secundário e não do primário [5, 5356]. Apesar disso, as alucinações parecem diferir da imagética, pois esta é gerada intencionalmente pelo indivíduo, enquanto a alucinação não é controlada e parece resultar de falhas em habilidades metacognitivas envolvidas na discriminação entre fontes externas e internas de informação [57].

Griffiths et al. [58] propuseram um modelo para explicar as alucinoses musicais de seis sujeitos sem sinais de psicose ou epilepsia com perda auditiva neurossensorial bilateral adquirida. Todos os pacientes passaram por avaliação otorrinolaringológica, neurológica e audiológica, investigação detalhada da fenomenologia das alucinações musicais, realizaram o exame de imagem funcional por ressonância magnética e tomografia por emissão de pósitrons. O modelo sugere que haja uma interação entre a percepção de padrões temporais (normal nos seis sujeitos), a imagética e o reconhecimento de alguns segmentos sonoros (distorcidos por causa perda auditiva) semelhantes a padrões musicais arquivados nas memórias desses pacientes. De acordo com os autores, não é necessário que a via aferente represente uma padrão musical 
verdadeiro para produzir uma alucinação auditiva. Em outras palavras, a própria atividade de codificação e reconhecimento de segmentos sonoros advindos de entradas sonoras distorcidas ou mal-reconhecidas por causa da perda auditiva ou mesmo de atividade espontânea das vias auditivas centrais reforçaria a imagética e a atividade espontânea, levando à geração de alucinose musical compatível com melodias conhecidas pelos sujeitos. Os autores sugerem que os limiares de percepção e imagética para atividade espontânea de pacientes com alucinose musical sejam diferentes dos limiares de outros pacientes com perda auditiva e sem alucinose, provavelmente por lesões vasculares nas estruturas relacionadas à percepção e imagética nos pacientes com alucinose musical. Os exames de imagem não evidenciaram ativação do córtex auditivo primário, mas sim do lobo temporal posterior, do gânglio basal direito, do cerebelo e do córtex frontal inferior. Assim, corroboram para o modelo proposto pelos autores, pois as áreas ativadas durante a piora da alucinose musical correspondem às áreas ativadas durante a imagética em sujeitos sem alucinose auditiva.

\subsection{Silêncio e via auditiva}

Mesmo na ausência de qualquer som, há sempre uma atividade neuronal espontânea no VIII par e em outros neurônios na via auditiva. Esta atividade aleatória e dessincronizada é filtrada pelo sistema auditivo e codificada como "silêncio".

Acreditava-se que cada sistema sensorial teria um limiar abaixo do qual um estímulo não geraria nenhuma percepção. Apesar da persistência desse conceito, Bialek [59] rejeita a noção de um limiar sensorial fixo. $O$ autor prefere a teoria de detectabilidade do sinal proposta por Lawson [60], APUD [59], que considera que 
estímulos arbitrários pequenos geram respostas proporcionalmente pequenas, mas não nulas. De acordo com esses autores, os limites de detectabilidade de estímulos pequenos são determinados pelo ruído.

Paradoxalmente, uma pequena quantia de ruído ativa componentes cocleares que aumentam a sensibilidade para sinais acústicos fracos. A este fenômeno não-linear é dado o nome de ressonância estocástica [61, 62]. Quando, em algum momento da história evolutiva as células ciliadas internas se desprenderam da membrana tectória, elas ganharam muito mais sensibilidade para sons fracos, pelo aproveitamento da ressonância estocástica, o que proporcionou vantagens óbvias na seleção das espécies. O movimento Browniano (colisões aleatórias de moléculas de ar na membrana timpânica) é um ativador constante da ressonância estocástica. A amplitude do movimento Browniano é de 1 a 2,7 nanometros (um nanômetro é um milhão de vezes menor que um milímetro). Uma pessoa com audição normal é capaz de detectar uma vibração sonora de meio nanômetro (da ordem do diâmetro de um átomo de hidrogênio).

$\mathrm{O}$ avanço da tecnologia tem permitido que se investiguem as respostas neuronais a diferentes estímulos por meio de medidas eletrofisiológicas ou exames de neuroimagem, que mostram as áreas cerebrais ativadas por diferentes tipos de estimulação acústica e até mesmo pela ausência parcial de sons (chamada por alguns autores de silêncio).

É sabido que a atividade do córtex auditivo é fortemente influenciada pelas entradas auditivas. Mas alguns estudos, citados a seguir, mostram evidências crescentes de que o córtex auditivo também pode ser ativado por entradas de outras modalidades sensoriais, o que nos força a rever o conceito de que as áreas corticais respondam 
exclusivamente a um a outro sentido [2]. Em outras palavras, pode-se encontrar ativação do córtex auditivo sem nenhum estímulo acústico.

Buscando confirmar o local e o tempo do resgate imagético para sons não-verbais, Hoshiyama et al. [4] fizeram um estudo com magnetoencefalografia (MEG) em sete sujeitos destros sem alterações auditivas ou neurológicas (média etária 31,1 \pm 3,1 anos). Os participantes assistiram a um vídeo com batidas de martelo em uma bigorna com som e sem som. Na primeira sessão de avaliação todos foram instruídos a não pensarem em nada enquanto assistiam à cena muda, enquanto na segunda sessão eles foram instruídos a imaginarem o som de marteladas enquanto assistiam ao mesmo vídeo. As duas sessões foram reproduzidas em outro dia para confirmação da reprodutibilidade dos resultados. Os resultados indicaram deflexões fortes na MEG durante o filme com som e sem som com imagética, mas nenhuma resposta consistente durante o filme mudo sem imagética. As áreas ativadas no resgate imagético do som do martelo foram o sulco inferior frontal e a região da ínsula, com predomínio do hemisfério direito, relacionado ao processamento de sons não-verbais. Os pesquisadores admitem não poderem excluir a contribuição da memória operacional na ativação do córtex auditivo primário, mas julgam que esta ocorreria em estágios posteriores ao da imagética.

Bunzeck et al. [5] realizaram um estudo com imagem funcional por ressonância magnética (RMf) para investigarem as bases neurais da imagética auditiva para sons complexos não correspondentes à linguagem ou à música. Na primeira condição do experimento (percepção), os sujeitos $(\mathrm{N}=8)$ assistiram a um filme com cenas familiares e ouviam seu som simultaneamente (exemplo: mulher secando o cabelo). Na segunda condição (imaginética), os participantes assistiam à mesma cena, mas sem som, e eram 
solicitados a imaginar o som correspondente à cena. Na terceira condição (controle), era apresentado um filme com imagens distorcidas e sem som. Para minimizar a interferência do ruído do scanner nos resultados da RMf foi aplicada uma técnica baseada no paradigma das amostras esparsas, que consiste na aquisição de cinco conjuntos funcionais 6 segundos após o início do estímulo com intervalos de 15 segundos de silêncio entre cada conjunto de aquisição, o que, segundo os autores, resultou ser eficiente. A comparação da situação de percepção de sons complexos com a situação controle mostrou ativação dos córteces auditivos primário e secundário (incluindo giro de Heschl e plano temporal) durante a percepção auditiva. Já a comparação da situação controle com a situação imagética mostrou respostas hemodinâmicas bilaterais apenas no córtex auditivo secundário (incluindo plano temporal), sem ativação significativa no córtex auditivo primário durante a imagética. Os pesquisadores discutem se a ativação do córtex auditivo secundário durante a apresentação do filme sem som seria mesmo decorrente da imagética ou de uma tentativa de resgate (ativação da memória) do som correspondente àquele filme. No entanto, eles consideraram impossível diferenciar o efeito da imagética e do resgate na reativação de áreas sensoriais específicas, pois ambas partilhariam os mesmos processos e as mesmas estruturas neurais.

Hunter et al. [1] examinaram a atividade basal de áreas auditivas corticais relacionadas à fala no silêncio. Foram avaliados 12 homens (média etária de 23 anos, \pm 3 anos) usando imagem funcional por ressonância magnética (RMf) com um protocolo que visa diminuir o efeito do ruído do scanner (utiliza as latências das respostas hemodinâmicas para permitir a apresentação do estímulo durante períodos de silêncio). 
Os participantes ouviam uma voz a cada 40 segundos através de fones de ouvidos providos de canceladores de ruído e, no restante do tempo, permaneciam em silêncio ( $\mathrm{T}=16$ minutos). As imagens foram adquiridas depois das apresentações vocais, que não eram aleatórias para evitar modulação da atividade de base da audição por efeito da vigilância auditiva. Os pesquisadores encontraram atividade espontânea, bilateral e intermitente dos córtices auditivos primário e secundário e do córtex cingular anterior durante o silêncio (em alguns casos superior a 30\% da atividade basal), mas com dominância do hemisfério esquerdo. Eles caracterizaram essa atividade espontânea como "presença de informação não-aletatória gerada internamente por substratos neurofisiológicos, tais como oscilação de canais iônicos em grande concentração em distintas áreas geradoras” (p. 193). Os autores enfatizaram que, neste contexto, a atividade espontânea se distingue de atividade aleatória, pois os deslocamentos das linhas de base são claramente aglomerados em distintos domínios temporais e espaciais. Seus achados mostraram ainda que a percepção da fala conteve a ativação espontânea das áreas específicas de fala do hemisfério esquerdo, o que poderia comprovar a hipótese de que a ativação evocada externa compete por recursos neurais com a ativação endógena. Os autores sugeriram que o modo de funcionamento normal do cérebro parece fornecer em si mesmo um substrato para as alucinações auditivas.

Voisin et al. [3] avaliaram por RMf a atividade cortical de 11 sujeitos saudáveis durante um breve período de silêncio em que os sujeitos estavam esperando o aparecimento de um som e deveriam apertar um botão assim que começassem a ouvi-lo. Durante o experimento o participante visualizava 2 setas opostas de cor verde. Uma das setas ficava vermelha para indicar de que lado viria o som (ruído filtrado), criando a 
situação de atenção no silêncio. O silêncio era mantido por períodos de tempo que variavam aleatoriamente de 0,5 a 7,5 segundos, quando a intensidade do estímulo subia e o sujeito apertava um botão de reposta. A obtenção das imagens começava assim que a resposta era dada, e era dado um período de descanso de 9 segundos, no qual as duas setas ficavam verdes. O período de descanso também foi escaneado. Os pesquisadores encontraram ativações frontais (córtex pré-frontal dorso-lateral direito e córtex frontal inferior), independentemente do lado em que o estímulo era procurado, o que corresponde às regiões de controle atencional. $\mathrm{O}$ achado mais notável foi a ativação do córtex temporal superior contra-lateral ao lado em que o som era esperado (giro de Herschel, plano temporal e áreas ântero-laterais). Os pesquisadores atribuíram seus resultados a dois fatores: resíduos da ativação prévia ao estímulo sonoro e efeito da atenção auditiva na ativação do córtex auditivo mesmo na ausência de estímulos sonoros.

Estudos sugerem que a conectividade funcional do córtex contribui para que seja possível que um indivíduo tenha experiências visuais conscientes mesmo na ausência de um estímulos externos [68-70]. As mesmas regiões corticais ativadas sob essas circunstâncias parecem ser também responsáveis pelo processamento de estímulos reais. Pesquisas nesta área estão avançando para explicar como um estímulo específico é codificado e armazenado no cérebro e como processos "top-down" são capazes de iniciar a atividade em áreas sensoriais primárias. King [2] supôs que a pré-ativação do córtex sensorial por mecanismos atencionais seja uma propriedade de todo o córtex sensorial, e não apenas do córtex visual. 
São raros os estudos comportamentais que avaliam o efeito do silêncio na via auditiva de indivíduos com audição normal. Heller e Bergman [7] pesquisaram a sensação auditiva de 80 indivíduos sem queixas auditivas, com idades entre 18 e 60 anos, que permaneceram em uma câmara à prova de som (ruído de fundo entre 15 e 18 dB) por 5 minutos. Antes de entrar na câmara, os pesquisadores pediram que os sujeitos anotassem em um papel qualquer som que ouvissem neste período. Surpreendentemente, $93,75 \%$ dos sujeitos referiram alguma sensação auditiva. Dentre os 23 tipos de sons relatados, $50 \%$ foram descritos como zumbido de abelha, "hum” e apito. Desde então, se aceita a idéia de que a maioria das pessoas tem um zumbido permanente, nãopatológico, que não é percebido no dia-a-dia devido à presença de sons ambientais concorrentes $[39,40,63-80]$

Este experimento foi replicado por Tucker et al. [8], que pesquisaram o efeito do silêncio no surgimento da percepção do zumbido em 120 adultos (60 homens e 60 mulheres) com idades entre 18 e 30 anos e com audição normal. Todos os indivíduos foram solicitados a anotar em um papel quaisquer sons que tivessem escutado no período em que estiveram dentro da cabina acústica ( $\mathrm{t}=20$ minutos). No total, $64 \%$ dos sujeitos $(n=77)$ relataram ter percebido algum som (incluindo sons referentes à pulsação cardíaca), sem diferença entre gêneros, mas com diferença significativa entre raças, em que caucasianos tiveram muito mais percepções auditivas (78\%) que os negros (38\%). Para todos os sujeitos a percepção do zumbido ocorreu antes do quarto minuto de silêncio.

Os resultados preliminares de outro estudo sobre o aparecimento do zumbido em indivíduos sem queixas auditivas e sem zumbido foram apresentados por Del Bo et al. 
[9]. Nesse estudo os participantes ( $\mathrm{N}=53$, de 19 a 29 anos, com média etária de 22 anos) foram instruídos a prestar atenção a sons que poderiam escutar enquanto estivessem dentro de uma câmara anecóica (ruído do piso inferior a 25 dB NPS) por duas sessões de cinco minutos. Antes de entrarem na câmara, os participantes leram uma lista de múltipla escolha com 24 sons (a maioria compatíveis com descrições de zumbido) para depois marcarem os sons que foram escutados. O diferencial entre a primeira e a segunda sessão foi a colocação de caixas de som dentro da câmara. Na primeira situação, $83 \%(\mathrm{n}=44)$ dos sujeitos relatou ter ouvido algum som e foram relatados em média 2,17 sons $(\mathrm{DP}=1,68)$. Já na segunda sessão, 92\% $(\mathrm{n}=49)$ relataram ter tido percepções auditivas, tendo sido reportados em média 2,58 sons $(\mathrm{DP}=1,65)$. $\mathrm{O}$ aumento da expectativa criada pelas caixas de som não foi estatisticamente significativo. "Buzz" e "hum" foram o sons mais referidos nesta pesquisa.

\subsection{Atenção auditiva}

A interpretação de um estímulo não depende apenas da integridade da via auditiva, mas também da atenção dada ao estímulo acústico, da motivação e da expectativa. Como será visto, diversos trabalhos comprovam a influência exercida pelo próprio sujeito na percepção auditiva.

A atenção gerada por um estímulo significativo pode ser automática ou voluntária. A diferença entre os dois tipos de atenção reside na ausência ou presença do controle consciente da atenção.

A atenção automática, ou involuntária, é caracterizada pela habilidade de direcionar a atenção para eventos sensoriais ou biológicos potencialmente relevantes 
(estímulos súbitos, contrastantes com o fundo ou estímulos significativos em um dado contexto) que ocorram fora do foco de atenção do sujeito [81-83]. É provável que tais eventos potencialmente relevantes intensifiquem o processamento sensorial-cognitivo, resultando no acionamento automático dos mecanismos de atenção. Assim, a atenção automática depende obrigatoriamente da interpretação contínua do sistema nervoso a respeito da importância dos estímulos de um dado momento. A determinação do grau de importância dada ao estímulo depende, por sua vez, de memórias pré-existentes [81].

Já a atenção voluntária ou seletiva permite que a informação relevante seja selecionada em detrimento de outras informações concomitantes. Seus mecanismos neurais envolvem tanto o aumento da atividade neural envolvida no processamento da informação relevante quanto a diminuição ou supressão da atividade neural correspondente aos estímulos irrelevantes [84, 85]. Mas a seletividade não significa meramente incluir uma informação relevante e negligenciar completamente a irrelevante. Ao contrário, as informações não atendidas também são obrigatoriamente registradas [82]. Apesar da aparente desvantagem, é esse processamento dos sinais irrelevantes que permitem a mudança rápida do foco de atenção e permite o acúmulo de evidências de regularidades do mundo sonoro, fundamentais para a eficiência da percepção e aquisição de linguagem, por exemplo.

Embora não sejam conhecidos com precisão todos os mecanismos de modulação “top-down” da rede neural envolvida na atenção, modelos teóricos sobre suas bases neurais baseiam-se em evidências experimentais de fisiologia celular, exames de neuroimagem funcionais e eletroencefalografia (EEG), que revelam aumento da atividade neural em áreas corticais representativas do estímulo sob atenção e em áreas específicas 
de atenção [85] e diminuição ou supressão da atividade neural correspondente aos estímulos irrelevantes.

Estudos de atenção seletiva sugerem que a magnitude da atividade neural possa ser modulada em função da limitação de recursos para processamento perceptual de múltiplos estímulos simultâneos [85, 86].

Gazzaley et al. [85] avaliaram a modulação da magnitude da atividade neural para percepção de estímulos seqüenciais em função das decisões internas guiadas por instruções. Os autores mostraram serem verdadeiras as seguintes hipóteses: (i) a instrução para lembrar de um estímulo resulta na modulação da magnitude da atividade neural e na velocidade do processamento cortical, (ii) a modulação ocorre em relação a um nível basal de atividade neural tanto no aumento (acima do nível basal) quanto na supressão (abaixo do nível basal) desta atividade, dependendo da instrução dada, (iii) a modulação "top-down” tem recursos limitados e, quando sua capacidade é excedida, seu desempenho fica comprometido. Dezoito indivíduos participaram do mesmo experimento em duas sessões nas quais os sinais do nível de oxigênio dependente do sangue (BOLD ou 'blood oxigen level dependent') e a atividade elétrica eram gravadas imagem funcional por ressonância magnética (RMf) relacionada a eventos e registros de potenciais relacionados a eventos (ERPs), unindo assim a alta definição espacial e temporal de cada exame, respectivamente. O experimento consistiu de quatro tarefas nas quais os participantes viam uma sequiência de quatro estímulos, duas faces e duas cenas, agrupadas aleatoriamente. As tarefas se diferenciaram pela instrução dada aos participantes sobre como processar os estímulos: (1) lembre das faces e ignore as cenas, (2) lembre das cenas e ignore as faces, (3) lembre das faces e das cenas, (4) assista 
passivamente às cenas e às faces, sem tentar avaliá-las ou lembrá-las. Após 9 segundos uma face ou cena era apresentada e o participante deveria responder se ela havia sido apresentada anteriormente (teste de reconhecimento pós-experimento). Os dados dos exames referem-se ao estágio de apresentação dos estímulos e foram obtidos nas regiões de interesse, a saber: córtex visual de associação seletiva para faces (área fusiforme ou AF) e para cenas (área parahipocampal ou APH). A magnitude dos sinais coletados nas áreas de interesse foi calculada e foram feitas comparações entre as tarefas.

As análises do BOLD revelaram que a atividade na APH foi maior para a instrução "lembre das cenas" que para a "ignore as cenas" (APH direita e esquerda: $p<0,00001$ ), enquanto a atividade na área seletiva para faces foi maior para "lembre das faces" que para "ignore as faces" ( $\mathrm{p}<0,005)$. As análises dos ERPs também revelaram modulação da magnitude da atividade elétrica comparável aos dados da MRfI da AF, com aumento da amplitude dos potenciais para lembre das faces versus ignore as faces $(\mathrm{p}<0,05)$. Também, a latência do pico do potencial analisado foi, em média, 10 ms mais recente para "lembre das faces" que para "ignore as faces" $(\mathrm{p}<0,05)$. Evidências de que os participantes ignoraram efetivamente o estímulo quando instruídos foram obtidos em um teste de reconhecimento pós-experimento, que revelou que as faces e cenas a serem ignoradas foram menos lembradas que as que deveriam ser lembradas (faces, $p<0,005$, cenas, $\mathrm{p}<0,001)$. Dados da RMf da APH demonstram diferenças significativas tanto no aumento da atividade para "lembre das cenas" em relação à "assista passivamente", quanto diminuição da atividade na área para assista "ignore a cena" em relação à "assista passivamente", o que indica existência tanto de aumento quanto a supressão da atividade neural em relação a um nível basal. Durante a instrução "lembre das faces e das cenas" o 
aumento da atividade neural não foi tão intenso quanto o observado nas instruções de lembrar faces ou cenas separadamente e não foi estatisticamente significativo quando comparado a "assista passivamente". O teste de reconhecimento pós-experimento revelou que as cenas e faces foram menos reconhecidas com essa instrução que com a "lembre faces ou cenas separadamente".

Portanto, os achados foram extremamente consistentes e fornecem fortes indícios de que as diferenças observadas foram decorrentes de modulações "top-down" de acordo com a instrução dada. Os autores sugerem que, assim como a amplificação da magnitude do sinal neural melhora a relação sinal-ruído, o processamento mais rápido refletiria um aumento na eficiência do processamento neural, facilitando também a extração da informação. Em outras palavras, a modulação “top-down” favoreceria a representação de uma informação relevante em um sistema competitivo.

Mitchell et al. [87] conseguiram descrever a influência da atenção na ativação de uma rede de regiões cerebrais atuantes nos processos “bottom-up” e “top-down”. Eles partiram da hipótese de que a atenção voluntária melhoraria o processamento da diferença da sensação de frequiência de tons através do recrutamento de regiões frontais, envolvidas no controle executivo e na geração de respostas, que modularia a atividade neural dos córtices auditivo primário e secundário. Para testá-la analisaram, pela imagem funcional por ressonância magnética, imagens do sistema temporo-frontoestriado de 14 adultos jovens, saudáveis e destros durante duas tarefas. Eles ouviram por fones de ouvido tons de ocorrência freqüente (90\% dos estímulos, de $1000 \mathrm{~Hz})$ e de ocorrência infreqüente $(10 \%$ dos estímulos, de $1064 \mathrm{~Hz})$ a aproximadamente $85 \mathrm{~dB}$. Na primeira etapa do estudo, deveriam pressionar um botão para o tom freqüente e outro 
para o infreqüente (condição com atenção auditiva ao “oddball”). Na segunda etapa, os sujeitos desempenharam uma tarefa de discriminação visual e foram instruídos a não prestar atenção nos estímulos auditivos (condição sem atenção auditiva ao "oddball”). A análise em conglomerados (“cluster”) de cada uma das áreas de interesse mostrou que os tons desviantes evocaram uma forte ativação do giro temporal superior nas duas condições, mas ainda mais forte na condição com atenção auditiva. Esta condição também é fortemente relacionada à ativação das regiões frontais (giro cingular anterior, giro frontal inferior e giro frontal medial) e estriadas.

Já sons repetidos provocam um efeito de adaptação de disparo neuronal do córtex auditivo primário (A1) para sons repetidos, chamado de efeito de adaptação para estímulos específicos. O efeito de adaptação para estímulos específicos ocorre sem atenção dirigida ao som, aparece rapidamente e são específicos para o estímulo. Baldeweg [88] discute estudos com potenciais relacionados a eventos (ERPs) e "Mismmatch Negativity" (MMN) que sustentam a idéia de que a atividade neural é diminuída depois de exposição a sons repetitivos. Segundo o autor, os ERPs também sugerem que com o aumento do número de repetições, o traço de memória para um estímulo específico pode ser detectado cada vez mais cedo em etapas mais anteriores do processamento, em níveis abaixo de A1 (giro de Heschl). Esta hipótese está apoiada em dois achados: a latência do MMN diminui de $120 \mathrm{~ms}$ depois de duas repetições do estímulo para 50 ms após 30 repetições, e os ERPs apresentam uma hierarquia, com geração de latências de até $50 \mathrm{~ms}$ em A1 e geração de picos mais tardios na borda e borda adjacente do plano temporal, conectados a áreas de projeção frontal e parietal. 
Para Badelweg, esses são indícios da existência de uma hierarquia de plasticidade "topdown”.

Resumindo, existem muitas publicações sobre a fisiopatologia do zumbido e da alucinação auditiva, sobre os efeitos da atenção no processamento da informação e alguns trabalhos a respeito dos efeitos do silêncio na via auditiva, mas não encontramos textos que explorassem explicitamente a relação entre temas. 


\section{4}

Métodos

\subsection{Casuística}

Para a seleção da amostra, foram considerados os seguintes critérios de inclusão:

- idade entre 18 e 65 anos;

- limiares audiométricos por via aérea iguais ou inferiores a 25 dB NA nas freqüências de 250 a $8000 \mathrm{~Hz}$ nas duas orelhas;

- ter curva timpanométrica tipo A, ou seja, com pico de complacência entre -50 e +50 DaPa [89];

- presença de emissões otoacústicas transientes.

Foram excluídos para este estudo os sujeitos que apresentassem:

- história de doenças neurológicas degenerativas;

- história de traumatismos cranianos;

- cirurgias otológicas prévias; ou

- presença de zumbido constante atual ou de história prévia de zumbido por mais de 30 dias; 
O quadro de voluntários desta pesquisa foi composto por indivíduos das Faculdades de Física e de Fonoaudiologia da Unicamp, da Maternidade de Campinas, da Escola Curumim e das empresas GAB Engenharia e Capital Humano, locais onde a pesquisa foi divulgada.

Foram avaliados 74 sujeitos, porém oito foram excluídos por apresentarem limiares audiométricos superiores a 25 dB NA em uma ou mais freqüências. Assim, a amostra final foi composta por 66 indivíduos.

O cálculo do tamanho amostral foi feito após a realização de um estudo-piloto em condições idênticas às propostas por este estudo, com os mesmos critérios de inclusão, mas sem o experimento 2 (detalhado no item 4.2.6) e sem qualquer referência à percepção visual. No estudo-piloto foram avaliados 11 sujeitos (54,5\% do sexo feminino) com média etária de 32,7 anos (DP = 7,4). Cinco sujeitos $(45,5 \%)$ tiveram alguma percepção auditiva durante o período de silêncio com atenção auditiva. Dois perceberam música e os outros três ouviram sons relativos a zumbido (mosquito, apito, cigarra).

\subsection{Procedimentos}

Foram realizados os seguintes procedimentos, na mesma ordem de apresentação:

4.2.1 Anamnese para coleta de dados sócio-demográficos e antecedentes pessoais (Anexo A).

4.2.2 Inspeção do meato acústico externo para verificação de presença de cerúmen ou corpo estranho. 
4.2.3 Audiometria tonal liminar por via aérea nas freqüências de 250, 500, 1000, 2000, 3000, 4000, 6000 e $8000 \mathrm{~Hz}$ conforme preconizado por Redondo e Lopes Filho [89].

\subsubsection{Emissões otoacústicas transientes (EOAT)}

Optou-se pelas EOAT pela rapidez do registro, pela larga informação espectral do teste e por sua confiabilidade para avaliar a função coclear [90, 91]. Os estímulos utilizados para obtenção do registro foram cliques não-lineares com intensidade variando de 76 a 86 dBNPS, captadas no modo QuickScreen do analisador de EOA. Antes do início do teste checou-se a adaptação da sonda no meato acústico externo (sonda de adulto com olivas de espuma) e do estímulo (check-fit). O exame foi interrompido na presença de resposta com no mínimo 50 ou no máximo 260 respostas captadas acima do nível de rejeição [92].

O espectro da resposta das EOAT correspondeu às frequiências obtidas dentro da faixa do estímulo utilizado e foi considerado em bandas de meia-oitava centralizadas em $1,2,3$ e 4 kHz [93].

Considerou-se a resposta como "presente" quando a amplitude da resposta por bandas, assim como a geral, foi maior ou igual a $3 \mathrm{~dB}$ em pelo menos três bandas, com reprodutibilidade maior ou igual a $50 \%$ em todas as bandas e reprodutibilidade geral de pelo menos 50\%. A estabilidade de sonda deveria ser maior ou igual a $70 \%$ [91] .

Os sujeitos que apresentaram alterações em qualquer etapa da avaliação auditiva foram encaminhados ao otorrinolaringologista. 
Cada participante realizou consecutivamente três experimentos dentro da cabina acústica, mas com diferentes exigências de atenção, como descrito a seguir. A ordem de apresentação dos experimentos variou para cada indivíduo.

4.2.5 Experimento "Hanói”: avaliação do efeito do silêncio sem atenção seletiva para a via auditiva. Cada indivíduo foi orientado a permanecer em uma cabina acústica durante cinco minutos e a solucionar um problema que exige raciocínio e respostas motoras (Torre de Hanói). A Torre de Hanói é um jogo composto por uma base, onde estão afixados três pequenos bastões em posição vertical, e cinco ou mais discos de diâmetros decrescentes, perfurados ao centro, que se encaixam nos bastões. Assim, a torre é formada pelos discos empilhados no bastão de uma das extremidades, que será chamada de casa 1 . O objetivo do jogo é transportar a torre para a casa 3, usando a intermediária 2 (Figura 2) com o menor número possível de movimentos desde que, em nenhuma etapa, uma peça maior fique pousada sobre outra de menor tamanho.

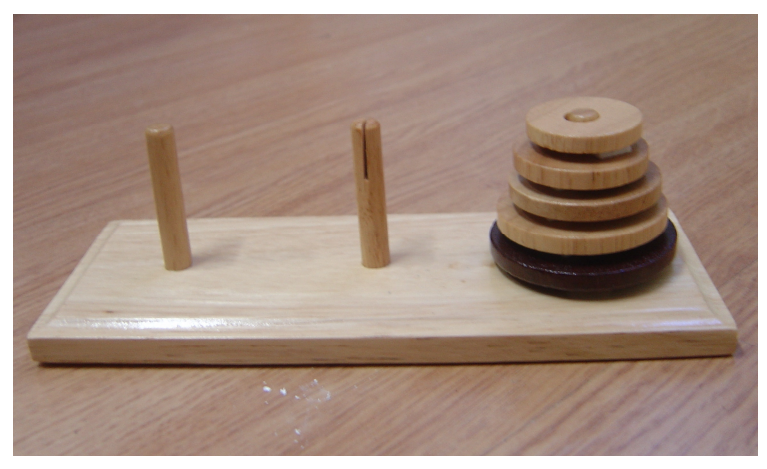

Figura 2. Torre de Hanói usada no experimento

Esta atividade tem sido usada por psicólogos e neuropsicólogos para a avaliação da capacidade de memória de trabalho e, principalmente de planejamento e solução de problemas. Em nosso estudo a torre de Hanói foi utilizada apenas para desviar a atenção 
da via auditiva. Essa era feita de madeira com placas de feltro em cada disco para diminuir o ruído entre as peças. Ainda assim, a manipulação das peças produziu ruído intermitente (em cada movimentação de peça) de 45 a 55 dB NPS, mas com ruído de fundo mínimo (chamado aqui de silêncio) nos períodos entre cada movimentação de peças.

Após uma explicação sobre o funcionamento da Torre de Hanói cada indivíduo recebeu a seguinte instrução: "Você vai tentar transportar todas as peças de uma torre para a outra, como eu lhe mostrei, durante cinco minutos. Se você terminar a tarefa antes, reinicie o jogo." Passado o tempo estipulado, o indivíduo foi indagado quanto à percepção de qualquer som durante o tempo em que ficou dentro da cabina, assim como suas características (tipo, localização e duração) e de qualquer mudança de luminosidade da cabina. Como o nível de ruído ambiental não tem influência sobre a via visual, esta pergunta foi usada para avaliar o quanto os participantes poderiam ser sugestionados pela pergunta.

Neste experimento, assim como nos dois próximos, não foram apresentados quaisquer sons e a luminosidade da cabina manteve-se sempre a mesma.

4.2.6 Experimento “atenção visual": avaliação dos efeitos da sugestão na percepção visual e do silêncio na percepção auditiva, com atenção voluntária seletiva para a via visual. Dentro da cabina acústica o indivíduo recebeu a seguinte instrução: "Talvez você perceba pequenas mudanças na luminosidade da cabina. Dentro de cinco minutos vou lhe perguntar se você percebeu alguma mudança e vou lhe pedir que me descreva o que percebeu. Também é possível que não haja nenhuma mudança." Passado 
o tempo estipulado, o indivíduo respondeu às mesmas perguntas sobre percepção auditiva e visual que foram feitas no experimento anterior.

4.2.7 Experimento "atenção auditiva": avaliação do efeito do silêncio, com atenção voluntária seletiva para a via auditiva. Estando dentro da cabina acústica o indivíduo recebeu uma instrução semelhante à instrução dada por Heller e Bergman: "Talvez você ouça um ou mais tipos de som. Escreva nesta folha de papel os tipos de sons que você ouvir e de onde você acha que ele está vindo. Se você não ouvir nada, não escreva nada." Passado o tempo estipulado, o indivíduo respondeu às mesmas perguntas sobre percepção auditiva e visual que foram feitas nos experimentos anteriores.

Para garantirmos que qualquer diferença de percepção auditiva entre o experimento 3 e os demais fosse decorrente da atenção auditiva e não de uma possível falha de memória nos experimentos anteriores (possivelmente contornado pelo registro escrito dos sons percebidos neste experimento), metade dos sujeitos recebeu a mesma instrução com a seguinte modificação: "Talvez você ouça um ou mais tipos de som. Se você ouvir um ou mais sons, guarde essas informações na sua memória. Dentro de cinco minutos vou lhe perguntar se você ouviu alguma coisa e vou lhe pedir que me descreva o que ouviu. Também é possível que você não ouça nada." Quarenta e sete por cento dos sujeitos escreveram suas respostas e $53 \%$ as relataram oralmente.

A ordem de apresentação dos experimentos foi pseudo-aleatória. Cada onze sujeitos fizeram os experimentos em ordens diferentes, respectivamente:

- torre de Hanói, atenção visual, atenção auditiva (HVA)

- torre de Hanói, atenção auditiva, atenção visual (HAV)

- atenção visual, torre de Hanói, atenção auditiva (VHA) 
- atenção visual, atenção auditiva, torre de Hanói (VAH)

- atenção auditiva, torre de Hanói, atenção visual (AHV)

- atenção auditiva, atenção visual, torre de Hanói (AVH).

Todos os dados foram coletados entre outubro de 2006 e janeiro de 2007.

\subsection{Equipamentos}

Para a inspeção do meato acústico externo, usou-se o otoscópio Riester, modelo Pen-Scope.

A audiometria e os experimentos foram realizadas sempre pela mesma profissional em cabina acústica (140 x $120 \mathrm{~cm}$, com $190 \mathrm{~cm}$ de altura) com duas caixas de som nas laterais da cabina (Figura 3). Durante os experimentos o audiômetro e as caixas de som permaneceram desligados.

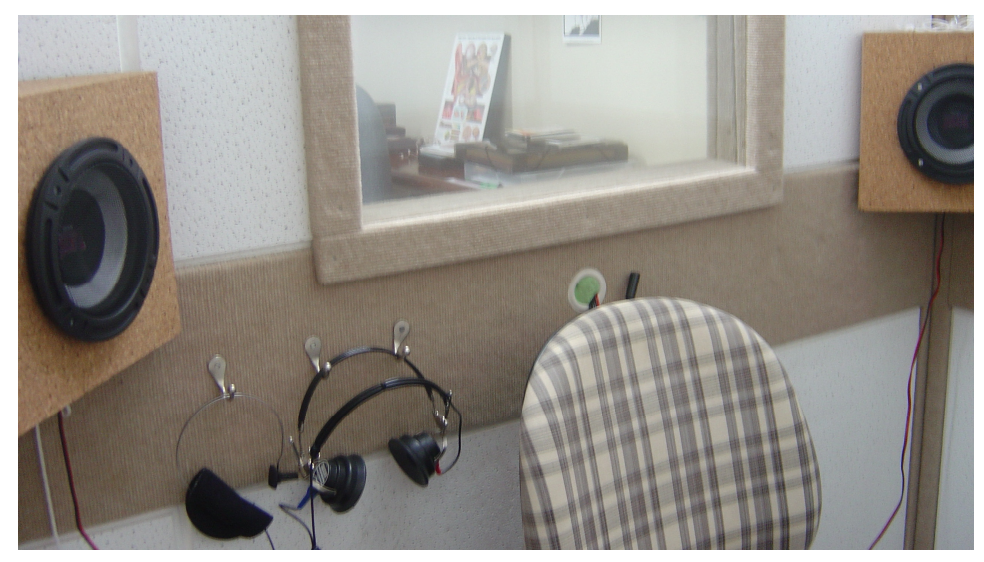

Figura 3. Foto de dentro da cabina audiométrica na qual os experimentos foram realizados

O ruído da cabina acústica foi medido por terços de oitava, na altura das orelhas, com o analisador de nível sonoro Brüel \& Kjær, modelo 2260, tipo 1 e com um microfone capacitativo Brüel \& Kjær, modelo 4189. As medidas estão de acordo com a 
norma ISO 8253-1, com a norma ABNT NBR 03-029.01-027/1 e com a Resolução no 296/2003 do Conselho Federal de Fonoaudiologia. As medidas em LZeq (média do nível de pressão sonora com resposta de freqüência plana, excluindo a resposta do microfone) em dB NPS (na escala linear) foram $25,3 \mathrm{~dB}$ em $250 \mathrm{~Hz}, 7,0 \mathrm{~dB}$ em $500 \mathrm{~Hz}, 4,8 \mathrm{~dB}$ em $1 \mathrm{KHz}, 3,8 \mathrm{~dB}$ em $2 \mathrm{KHz}, 4,9 \mathrm{~dB}$ em 3,15 KHz, 5,6 dB em $4 \mathrm{KHz}, 7,1 \mathrm{~dB}$ em 6,3 KHz e 7,4 dB em $8 \mathrm{KHz}$.

A audiometria foi realizada com o audiômetro Interacoustics AC33 com fones TDH-39, ambos calibrados conforme a norma ANSI S3.6-1996.

A coleta das emissões otoacústicas transientes (EOAT) foi feita em uma sala silenciosa com o analisador de emissões cocleares ILO 292, fabricado pela Otodynamics (versão 5.60y) acoplado a um microcomputador portátil Toshiba.

\section{4 Ética}

Esta pesquisa foi aprovada pelo Comissão de Ética para Análise de Projetos de Pesquisa (CapPesq) sob o protocolo $\mathrm{n}^{\circ}$. 866/05. Após terem manifestado interesse em participar deste trabalho, todos os indivíduos receberam esclarecimentos sobre a pesquisa pela própria pesquisadora, individualmente. Todos os indivíduos que participaram desta pesquisa assinaram o termo de consentimento livre e esclarecido.

\subsection{Análises}

Após a coleta dos dados, foram analisados: 
- porcentagem de indivíduos que perceberam algum som, sem atenção auditiva (experimentos Hanói e atenção visual) e com atenção auditiva (experimento atenção auditiva).

- porcentagem de indivíduos que perceberam alguma mudança na luminosidade da cabina, sem atenção visual (experimentos Hanói e atenção auditiva) e com atenção visual (experimento atenção visual).

- relação entre as variáveis de controle e as percepções auditivas e visuais com e sem atenção auditiva.

- análise das características das percepções auditivas dos sujeitos nos experimentos.

As variáveis numéricas foram descritas por sua média, desvio-padrão, valores mínimo e máximo. As variáveis categóricas foram descritas por sua distribuição de freqüências absolutas (n) e relativas (\%). A homogeneidade entre as respostas positivas e negativas para cada teste, segundo as variáveis de controle foi avaliada através do teste de qui-quadrado ou exato de Fisher, quando uma das frequiências absolutas foi inferior a 5. Para eventos pareados foi usado o teste McNemar.

Foram considerados significantes valores de $p<0,05$ em testes bi-caudais. O software utilizado para análise foi o SAS versão 8.02. 


\section{Resultados}

A distribuição dos sujeitos de acordo com idade e sexo é mostrada na tabela 1 e a distribuição em função do grau de escolaridade é mostrada na tabela 2. As idades mínimas e máximas dos participantes foram de 19 e 64 anos, respectivamente.

Tabela 1 - Distribuição dos sujeitos de acordo com idade e sexo

\begin{tabular}{ccccc}
\hline Sexo & $\mathbf{n}$ & $\mathbf{\%}$ & Media etária & DP \\
\hline Feminino & 34 & $51,5 \%$ & 37,1 & 10,0 \\
Masculino & 32 & $48,5 \%$ & 37,5 & 9,7 \\
\hline TOTAL & $\mathbf{6 6}$ & $\mathbf{1 0 0 \%}$ & $\mathbf{3 7 , 3}$ & $\mathbf{9 , 8}$ \\
\hline
\end{tabular}

Os participantes apresentaram média tonal (de 250 a $8000 \mathrm{~Hz}$ ) de 4,13 dBNA $(\mathrm{DP}=4,13)$ para a orelha direita e de 4,17 dBNA $(\mathrm{DP}=4,32)$ para a orelha esquerda.

A Tabela 2 apresentam a distribuição dos indivíduos de acordo com o nível de escolaridade. 
A freqüência de percepção auditiva nos experimentos com torre de Hanói, atenção visual e atenção auditiva estão na Tabela 3.

Tabela 2 - Distribuição dos sujeitos em função do nível de escolaridade

\begin{tabular}{lcc}
\hline Grau de instrução & $\mathrm{n}$ & $\%$ \\
\hline $\mathbf{1}^{\mathbf{o}}$ grau incompleto & 11 & $16,7 \%$ \\
$\mathbf{1}^{\mathbf{o}}$ grau completo & 5 & $7,6 \%$ \\
$\mathbf{2}^{\mathbf{o}}$ grau incompleto & 3 & $4,5 \%$ \\
$\mathbf{2}^{\mathbf{o}}$ grau completo & 8 & $12,1 \%$ \\
Universitário incompleto & 7 & $10,6 \%$ \\
Universitário completo & 13 & $19,7 \%$ \\
Pós-graduação & 19 & $28,8 \%$ \\
\hline TOTAL & $\mathbf{6 6}$ & $\mathbf{1 0 0 \%}$ \\
\hline
\end{tabular}

Tabela 3- Freqüência de percepção auditiva e visual nos experimentos com torre de Hanói, atenção visual e atenção auditiva

\begin{tabular}{llccc}
\hline Experimentos & \multicolumn{2}{c}{ Percepção Auditiva } & \multicolumn{2}{c}{ Percepção Visual } \\
& $\mathbf{n}$ & $\boldsymbol{\%}$ & $\mathbf{n}$ & $\%$ \\
\hline Hanói & 13 & $19,7 \%$ & 4 & $6,1 \%$ \\
Atenção visual & 30 & $45,5 \%$ & 10 & $15,2 \%$ \\
Atenção auditiva & 45 & $68,2 \%$ & 3 & $4,5 \%$ \\
\hline
\end{tabular}

O Gráfico 1 mostra a frequiência de percepção auditiva e visual nos experimentos com torre de Hanói, com atenção visual e com atenção auditiva. 


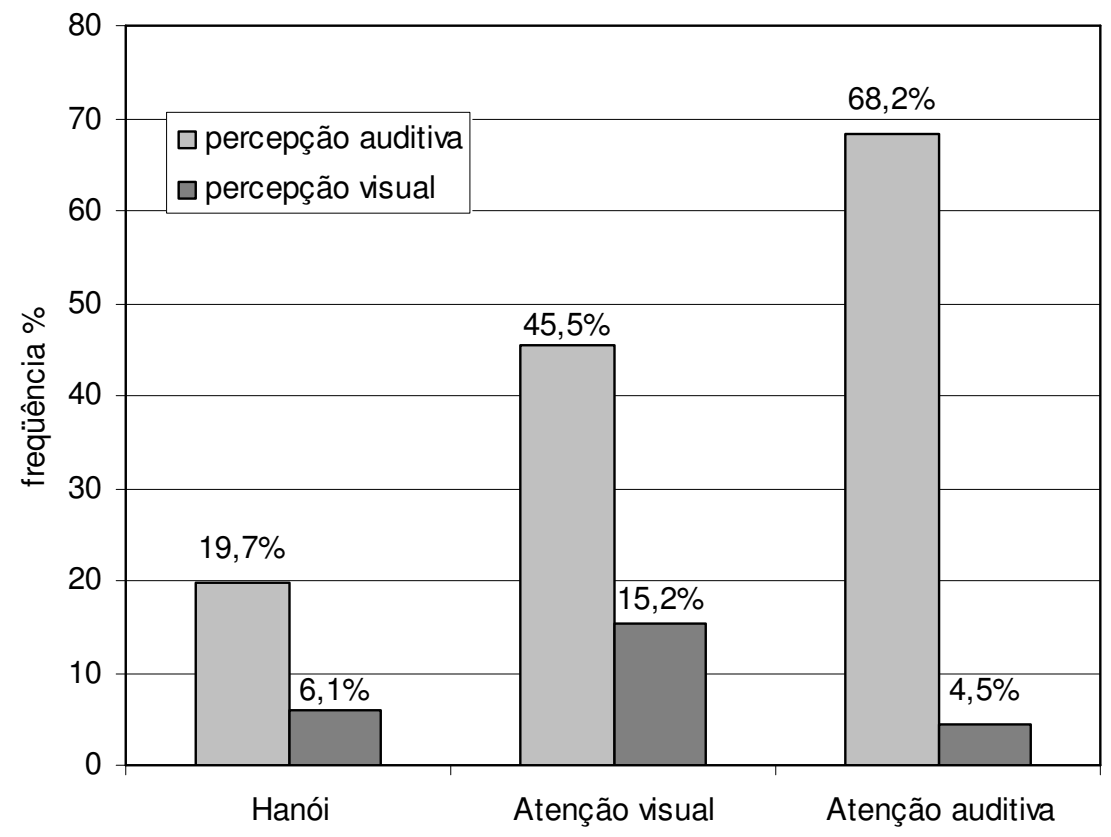

Gráfico 1 - Freqüência de percepção auditiva e visual nos experimentos com torre de Hanói, com atenção visual e com atenção auditiva

A diferença entre os experimentos Hanói, atenção visual e atenção auditiva para a incidência de percepções auditivas e visuais é apresentada na Tabela 4.

Na Tabela 5 observa-se a diferença entre a ocorrência de percepção auditiva e visual para cada experimento. 
Tabela 4 - Diferença entre os testes Hanói, atenção visual e atenção auditiva nas percepções auditiva e visual

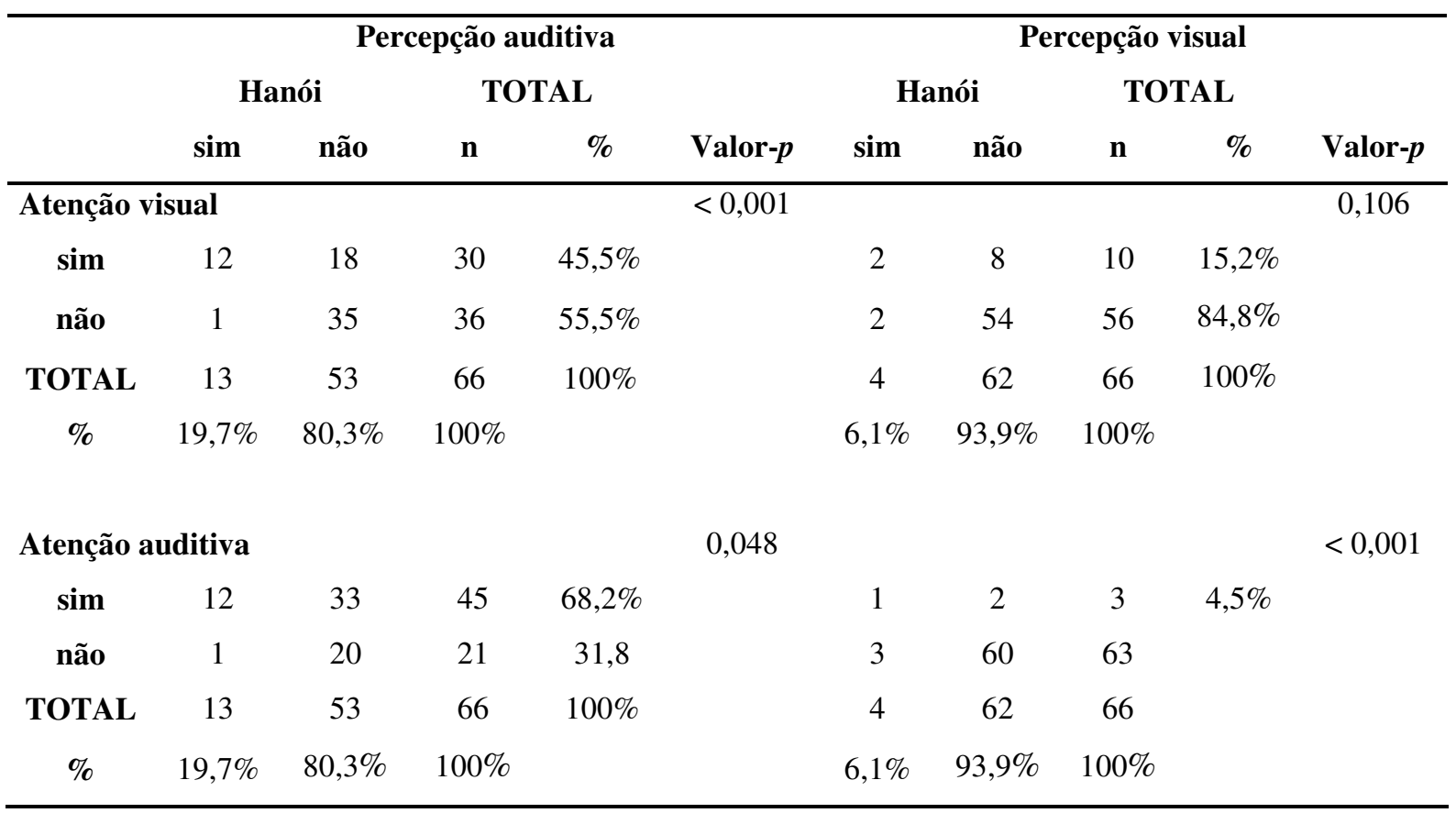

Teste Exato de Fisher

Tabela 5 - Diferença entre a ocorrência de percepção auditiva e visual para cada experimento

\begin{tabular}{cccccc}
\hline Experimentos & \multicolumn{4}{c}{ Percepção visual } & \multicolumn{3}{c}{ Percepção auditiva } & \\
& $\mathbf{n}$ & $\boldsymbol{\%}$ & $\mathbf{n}$ & $\boldsymbol{\%}$ & Valor-p \\
\hline Hanói & 4 & 6,1 & 13 & 19,7 & 0,035 \\
Atenção visual & 10 & $15,2 \%$ & 30 & $45,5 \%$ & $<0,001$ \\
Atenção auditiva & 3 & $4,5 \%$ & 45 & $68,2 \%$ & $<0,001$ \\
\hline
\end{tabular}

Teste de McNemar

O estudo do efeito da faixa etária sobre a percepção auditiva com atenção auditiva é apresentado na Tabela 6. 
Tabela 6 - Distribuição da percepção auditiva com atenção auditiva em função da faixa etária dos sujeitos

\begin{tabular}{|c|c|c|c|c|c|c|}
\hline \multirow{3}{*}{ Faixa etária } & \multicolumn{6}{|c|}{ Percepção auditiva com atenção auditiva } \\
\hline & \multicolumn{2}{|c|}{ Sim } & \multicolumn{2}{|c|}{ Não } & \multicolumn{2}{|c|}{ TOTAL } \\
\hline & n & $\%$ & $\mathbf{N}$ & $\%$ & $\mathbf{n}$ & $\%$ \\
\hline 18 a 33 anos & 15 & $68,2 \%$ & 7 & $31,8 \%$ & 22 & $33,3 \%$ \\
\hline 34 a 40 anos & 17 & $77,3 \%$ & 5 & $22,7 \%$ & 22 & $33,3 \%$ \\
\hline mais de 40 anos & 13 & $59,1 \%$ & 9 & $48,9 \%$ & 22 & $33,3 \%$ \\
\hline TOTAL & 45 & $68,2 \%$ & 21 & $31,8 \%$ & 66 & $100 \%$ \\
\hline
\end{tabular}

Cortes realizados por tercis - $33 \%$ e $66 \%$ da amostra

Teste de Qui-quadrado $p=0,4330$

A Tabela 7 mostra o estudo da percepção auditiva nos experimentos $\mathrm{H}, \mathrm{AV}$ e AA segundo variáveis de controle. A escolaridade foi agrupada em três categorias: $1^{\text {o }}$ grau completo e incompleto, $2^{\circ}$ grau completo e incompleto e superior e completo e incompleto e pós-graduação. A história positiva de tontura e de zumbido refere-se a episódios anteriores de curta duração (um dia). Para o estudo do efeito da exposição pregressa a nível de pressão sonora elevada (ocupacional, no lazer e por trauma acústico) os sujeitos foram separados em função da exposição a um único fator, a mais de um fator ou a nenhum. 
Tabela 7 - Estudo da percepção auditiva nos experimentos com torre de Hanói, com atenção visual e com atenção auditiva segundo variáveis de controle

\begin{tabular}{|c|c|c|c|c|c|c|c|c|c|}
\hline \multirow[t]{2}{*}{ Percepção Visual } & \multicolumn{2}{|c|}{$\begin{array}{c}\text { Torre de } \\
\text { Hanói }\end{array}$} & \multirow{2}{*}{$\begin{array}{c}\text { Valor- } \\
p\end{array}$} & \multicolumn{2}{|c|}{$\begin{array}{c}\text { Atenção } \\
\text { Visual }\end{array}$} & \multirow{2}{*}{$\begin{array}{c}\text { Valor- } \\
p\end{array}$} & \multicolumn{2}{|c|}{$\begin{array}{c}\text { Ateção } \\
\text { Auditiva }\end{array}$} & \multirow{2}{*}{$\begin{array}{c}\text { Valor- } \\
p\end{array}$} \\
\hline & $\mathbf{n}$ & $\%$ & & $\mathbf{n}$ & $\%$ & & $\mathbf{n}$ & $\%$ & \\
\hline Sexo & & & 1,000 & & & 1,000 & & & 1,000 \\
\hline feminino $(n=34)$ & 2 & $5,9 \%$ & & 5 & $14,7 \%$ & & 2 & $5,9 \%$ & \\
\hline masculino $(n=32)$ & 2 & $6,3 \%$ & & 5 & $15,6 \%$ & & 1 & $3,1 \%$ & \\
\hline Escolaridade & & & 0,239 & & & 0,706 & & & 0,841 \\
\hline $1^{\circ} \operatorname{grau}(\mathrm{c} / \mathrm{i})(\mathrm{n}=16)$ & 2 & $12,5 \%$ & & 3 & $18,8 \%$ & & 2 & $12,5 \%$ & \\
\hline $\begin{array}{l}2^{\circ} \text { grau }(\mathrm{c} / \mathrm{i})(\mathrm{n}=11) \\
\text { superior e pós- } \\
\text { graduação }\end{array}$ & 1 & $9,1 \%$ & & 2 & $18,2 \%$ & & 1 & $9,1 \%$ & \\
\hline$(\mathrm{n}=39)$ & 1 & $2,6 \%$ & & 5 & $12,8 \%$ & & 3 & $7,7 \%$ & \\
\hline Diabetes & & & 1,000 & & & 1,000 & & & 1,000 \\
\hline $\operatorname{sim}(n=1)$ & 0 & $0,0 \%$ & & 0 & $0,0 \%$ & & 0 & $0,0 \%$ & \\
\hline não $(\mathrm{n}=65)$ & 4 & $6,2 \%$ & & 10 & $15,4 \%$ & & 3 & $4,6 \%$ & \\
\hline Hipertensão & & & 1,000 & & & 0,342 & & & 1,000 \\
\hline $\operatorname{sim}(n=8)$ & 0 & $0,0 \%$ & & 0 & $0,0 \%$ & & 0 & $0,0 \%$ & \\
\hline não $(\mathrm{n}=58)$ & 4 & $6,9 \%$ & & 10 & $17,2 \%$ & & 3 & $5,2 \%$ & \\
\hline Tontura & & & 0,148 & & & 0,728 & & & 0,273 \\
\hline ausente $(n=40)$ & 4 & $10,0 \%$ & & 7 & $17,5 \%$ & & 3 & $7,5 \%$ & \\
\hline alguma vez $(n=26)$ & 0 & $0,0 \%$ & & 3 & $11,5 \%$ & & 0 & $0,0 \%$ & \\
\hline Zumbido & & & 0,527 & & & 0,351 & & & 1,000 \\
\hline ausente $(\mathrm{n}=55)$ & 3 & $5,5 \%$ & & 7 & $12,7 \%$ & & 3 & $5,5 \%$ & \\
\hline alguma vez $(n=11)$ & 1 & $9,1 \%$ & & 3 & $27,3 \%$ & & 0 & $0,0 \%$ & \\
\hline Exposição a NPSE & & & 0,800 & & & $0,502 *$ & & & $0,581 *$ \\
\hline não $(\mathrm{n}=26)$ & 5 & $19,2 \%$ & & 14 & $53,8 \%$ & & 18 & $69,2 \%$ & \\
\hline $\begin{array}{l}\text { a um unico fator }(n= \\
26)\end{array}$ & 6 & $23,1 \%$ & & 11 & $42,3 \%$ & & 19 & $73,1 \%$ & \\
\hline $\begin{array}{l}\text { a mais de um fator }(n= \\
14)\end{array}$ & 2 & $14,3 \%$ & & 5 & $35,7 \%$ & & 8 & $57,1 \%$ & \\
\hline
\end{tabular}

*Teste de Qui-Quadrado

Teste Exato de Fisher

c / i = completo e incompleto

NPSE $=$ nível de pressão sonora elevado 
Usando-se o Teste de Fischer para comparar a frequiência de percepção visual positiva nos experimentos em função da ordem de apresentação (primeiro, segundo ou terceiro experimento) obtiveram-se os valores- $p$ 1,000 para $\mathrm{H}, 0,219$ para AV e 1,000 para AA. Com mesma análise para percepção auditiva o valor- $p$ para $\mathrm{H}$ foi de 0,135 , para AV 0,480 e para AA foi de 0,231 (teste Qui-quadrado usados para os dois últimos). Portanto, não foi observada nenhuma alteração na distribuição das respostas positivas para percepção visual e auditiva em função da ordem de apresentação dos experimentos.

A resposta oral mostrou-se equivalente à resposta escrita para a percepção auditiva (valor $p=0,942)$.

As descrições ipsis literis das percepções auditivas nos experimentos $\mathrm{H}, \mathrm{AV}$ e AA são apresentadas no anexo B.

A quantidade de percepções auditivas por sujeito variou em cada experimento, como mostra a Tabela 8 .

Tabela 8 - Número de percepções auditivas por cada sujeito em cada experimento

\begin{tabular}{ccccccc}
\hline $\begin{array}{c}\text { Número de percepções } \\
\text { auditivas }\end{array}$ & \multicolumn{2}{c}{ Hanói } & \multicolumn{2}{c}{ Atenção visual } & \multicolumn{2}{c}{ Atenção auditiva } \\
\hline 1 & $\mathbf{n}$ & $\mathbf{\%}$ & $\mathbf{N}$ & $\mathbf{\%}$ & $\mathbf{n}$ & \% \\
\hline 2 & 11 & $84,6 \%$ & 27 & $90,0 \%$ & 24 & $53,3 \%$ \\
3 & 2 & $15,4 \%$ & 2 & $6,7 \%$ & 14 & $31,1 \%$ \\
4 & --- & --- & 1 & $3,3 \%$ & 4 & $8,9 \%$ \\
5 & --- & --- & --- & --- & 2 & $2,2 \%$ \\
6 & --- & --- & --- & --- & 2 & $2,2 \%$ \\
\hline TOTAL & --- & --- & --- & -- & 2 & $2,2 \%$ \\
\hline
\end{tabular}

Para favorecer a análise das percepções auditivas dos sujeitos, foram criadas as seguintes categorias que contemplam a característica predominante da percepção 
descrita: chiado, apito, "hum', água corrente, insetos, música, vozes, outras e miscelânea (para duas ou mais percepções distintas).

As percepções auditivas predominantes por categorias nos experimentos com torre de Hanói, atenção visual e atenção auditiva estão nos gráficos 2, 3 e 4, respectivamente.

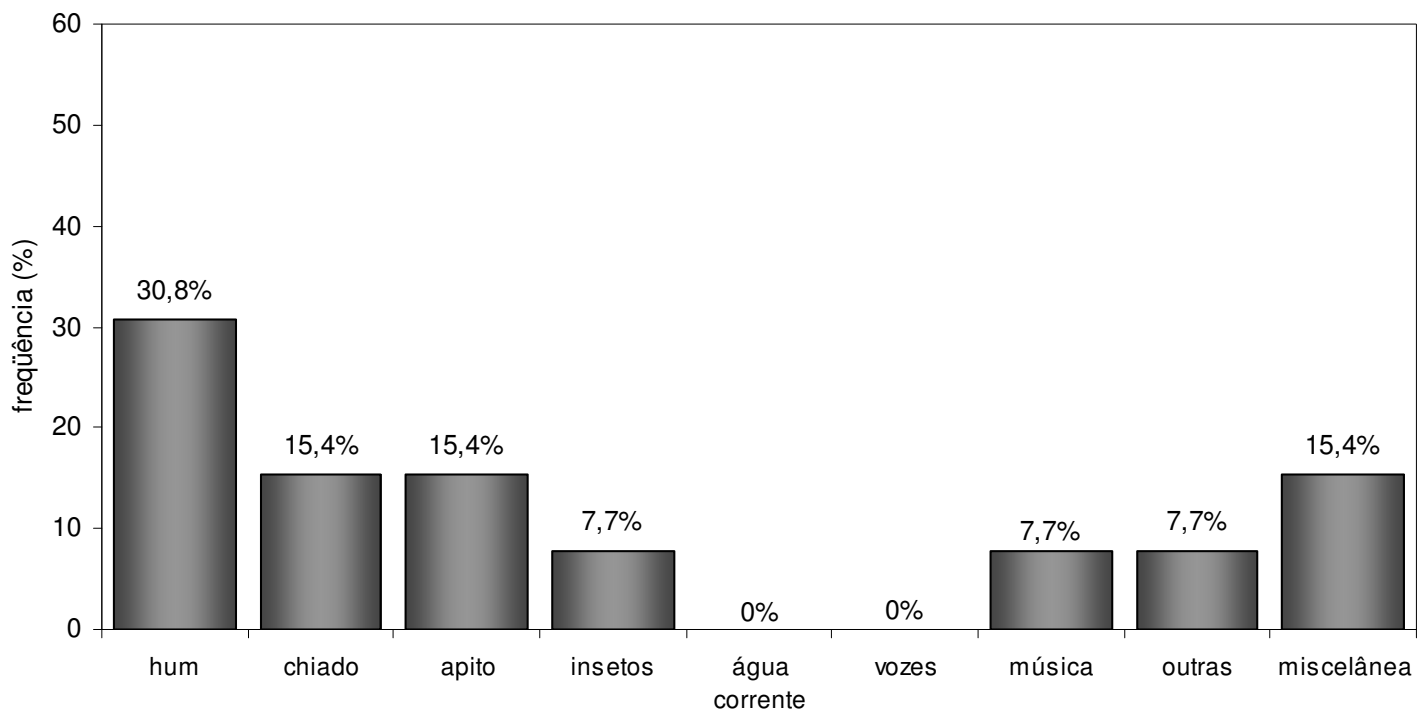

Gráfico 2 - Descrição das percepções auditivas predominantes com torre de Hanói (n = 13) 


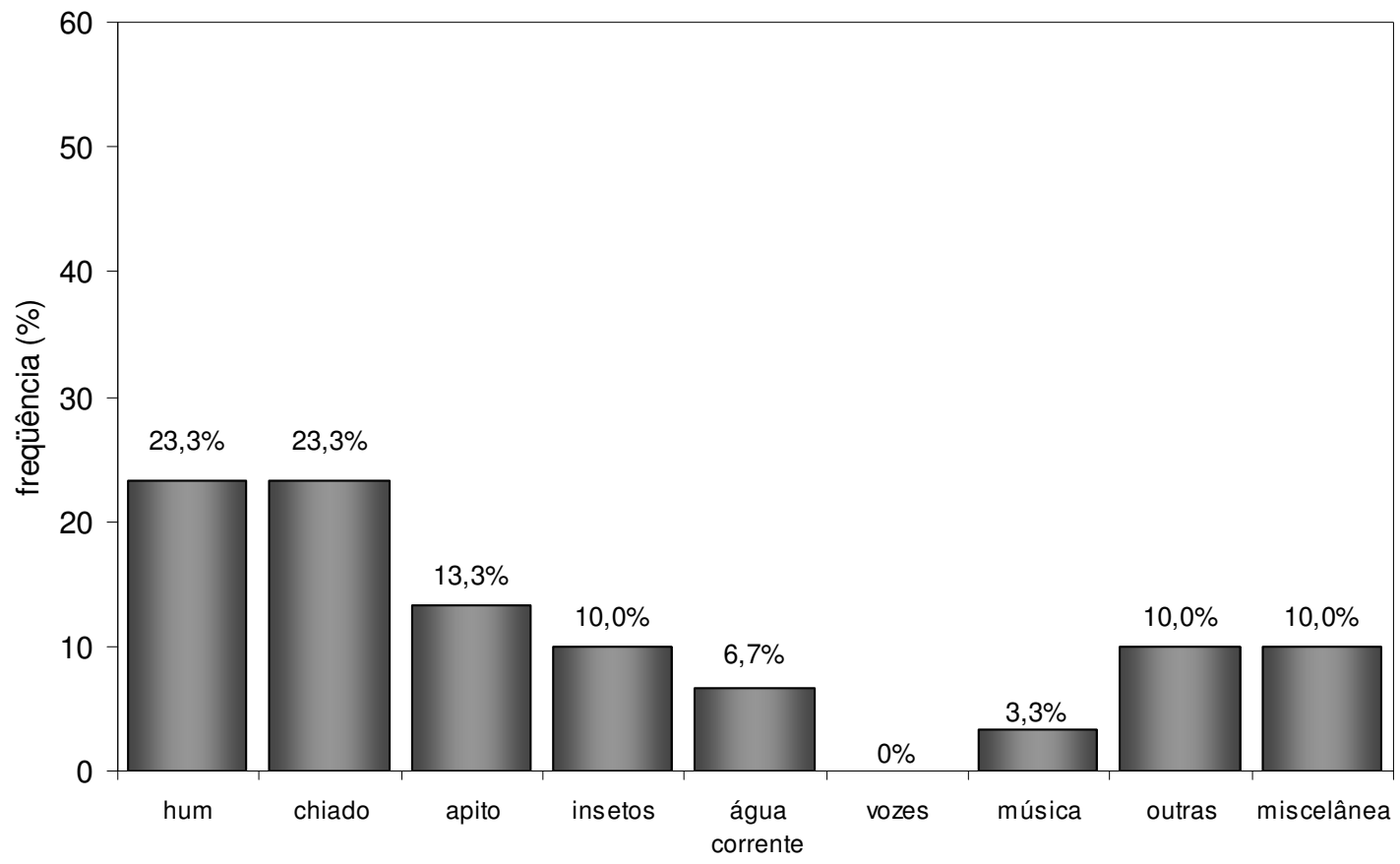

Gráfico 3 - Descrição da percepção auditiva com atenção visual (n=30)

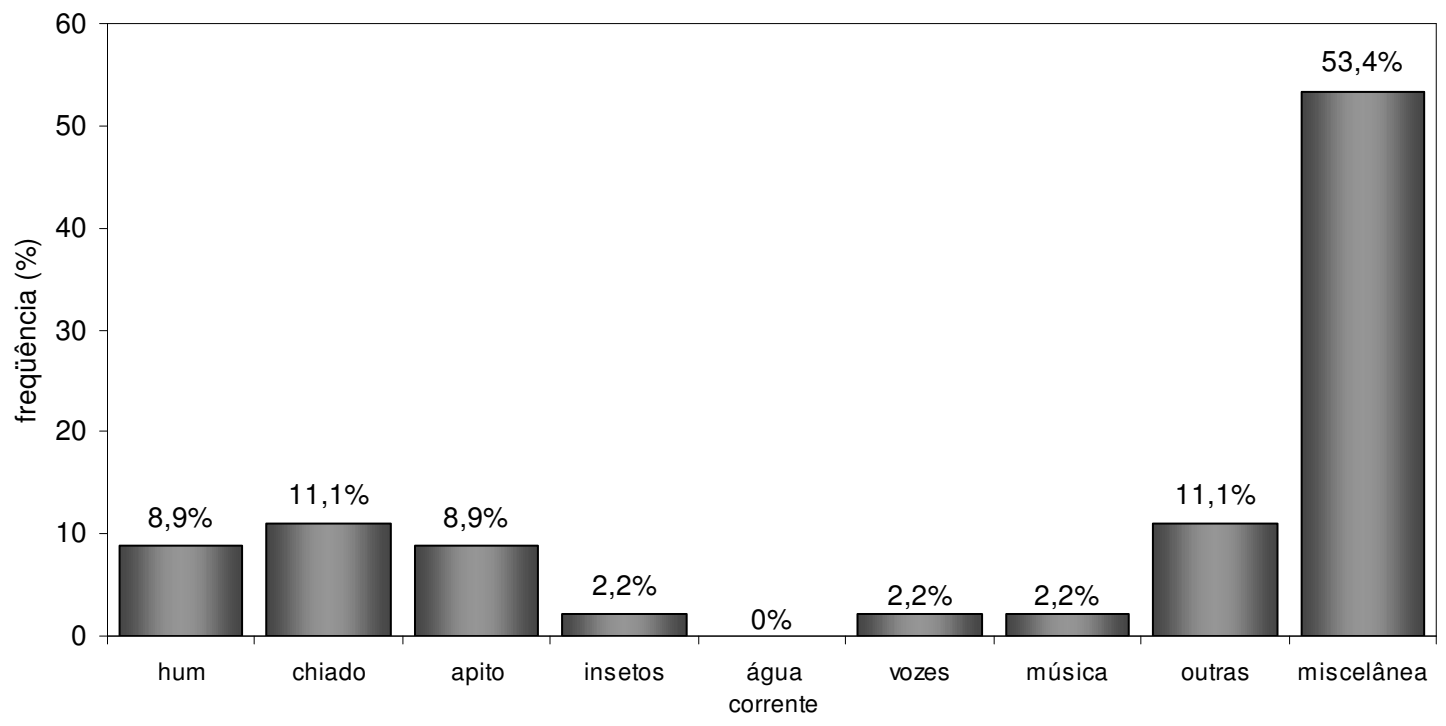

Gráfico 4 - Descrição da percepção auditiva com atenção auditiva (n=45) 
Na categoria miscelânea do experimento H $(n=2)$ estão "chiado e outras", "hum e outras", e no experimento AV (n=3) estão "chiado e outras", "apito e inseto" e "hum e outras". Já no experimento AA, dos 24 sujeitos que tiveram dois ou mais tipos de percepções diferentes, 79,2\% $(n=19)$ tiveram percepções categorizadas como "outras". Assim, a soma dos sujeitos que relataram ter percebido "música", "vozes", "outras" em “miscelânea" equivaleu a 57,8\% dos que tiveram alguma percepção auditiva e a 39,9\% da amostra completa $(n=26)$.

Sempre que o sujeito referia alguma percepção auditiva, era questionado sobre sua localização. As respostas variaram entre sensação de que o som era proveniente de seus ouvidos ou cabeça, das caixas de som ou de algum outro ponto dentro da cabina, de fora da cabina, indefinido (quando o sujeito não tinha certeza da fonte do "som") e misto (combinação de duas ou mais das anteriores). No experimento AA, 33,3\% dos participantes $(n=15)$ tiveram a sensação de que o estímulo que perceberam vinha das caixas de som ou de algum outro ponto de dentro da cabina. Vinte por cento $(n=9)$ acharam que o som vinha de seus próprios ouvidos ou cabeça, 17,7\% (n=8) tinham a impressão de que ele estava sendo produzido fora da cabina, 20,0\% localizaram mais de uma fonte sonora (ouvidos e caixas de som, fora e dentro da cabina, etc) e $8,9 \%(n=4)$ não souberam definir a origem do "som" escutado. 


\section{Discussão}

Neste estudo encontramos fortes evidências de que indivíduos com audição normal e sem zumbido podem experimentar uma percepção auditiva fantasma quando permanecem por um período curto de silêncio sustentado. Mais notoriamente, observamos que a combinação do silêncio com a atenção seletiva para a via auditiva multiplica esse efeito em mais de três vezes, ou seja, os diferentes estados de atenção parecem ter um papel importantíssimo na percepção auditiva fantasma.

Discutiremos a seguir: as relações entre as percepções auditivas e visuais nos três experimentos, Hanói (H), Atenção Visual (AV) e Atenção Auditiva (AA); o papel das características sócio-demográficas e das variáveis de controle no aparecimento de percepções auditivas fantasma; a influência da ativação "top-down" nas percepções auditivas fantasma; e implicações da nossa pesquisa para a compreensão e o tratamento do zumbido e das alucinoses auditivas. 


\subsection{Comparação entre as percepções auditivas e visuais}

Nossos resultados foram absolutamente baseados nos relatos dos sujeitos dessa pesquisa. Como não tínhamos um meio direto e independente de verificar suas respostas, incluímos em todos os experimentos questões sobre percepções visuais. Se a pergunta sobre a percepção de sons fosse um viés que induzisse respostas positivas, então a quantidade de relatos positivos para percepção visual seria semelhante à de relatos positivos para percepção auditiva, o que não ocorreu (Tabela 5). Portanto, a diferença entre o índice de percepção visual e auditiva certamente reflete o efeito do silêncio sustentado no surgimento da percepção auditiva fantasma.

Seria possível inferir que a ordem de apresentação dos experimentos pudesse influenciar os resultados tanto por um efeito de aprendizagem de que depois do período de silêncio há perguntas sobre percepções auditivas e visuais, quanto por um possível efeito do tempo de permanência no silêncio (cinco minutos por experimento, portanto 15 minutos após o terceiro experimento). Entretanto, não houve nenhuma influência da ordem de apresentação dos experimentos sobre os resultados, o que fortalece a confiabilidade de nossos achados.

No experimento com atenção auditiva (AA), metade dos sujeitos escreveu suas percepções auditivas e outra metade relatou o que lembrava após o experimento. A razão dos dois tipos de resposta foi permitir a melhor comparação possível do nosso estudo com o de Heller e Bergman [7] (que usou respostas escritas durante o experimento) e também com os nossos demais experimentos, nos quais as respostas eram orais. Não houve diferença estatisticamente significativa entre os dois tipos de resposta. Portanto, 
podemos naturalmente comparar os resultados de toda a amostra com a pesquisa de Heller e Bergman [7] e também com nossos outros experimentos.

Como a pesquisa da percepção visual teve como objetivo único afastar quaisquer dúvidas a respeito da confiabilidade das respostas dos participantes, a partir de agora focaremos a discussão apenas nas percepções auditivas.

\subsection{Características sócio-demográficas}

Dentre as variáveis estudadas, apenas o fator idade pôde ser comparado com estudos semelhantes ao nosso, já que as outras variáveis não foram exploradas por seus autores. Heller e Bergman [7] avaliaram sujeitos de 18 a 60 anos, semelhante à faixa etária estudada por nós, mas não avaliaram possíveis diferenças entre os mais jovens e os mais velhos. Tucker et al. [8] e Del Bo et al. [9] estudaram apenas adultos jovens (18 a 30 anos). A comparação de seus resultados com os nossos para a faixa etária de 18 a 33 anos (Tabela 6) não mudou o grau de diferença entre nossos achados.

Não encontramos relações estatisticamente significativas entre a percepção auditiva fantasma e o nível de escolaridade na incidência de percepção auditiva em nenhum dos experimentos realizados (Tabela 7), mas também não encontramos dados na literatura que possam ser comparados com os nossos.

As variáveis tontura prévia, hipertensão arterial e exposição prévia a níveis elevados de pressão sonora também não interferiram no índice de percepção auditiva fantasma (Tabela 7), ao contrário do que poderia ser esperado, já que estas variáveis são conhecidamente relacionadas ao zumbido [17, 36, 80, 94, 95]. Embora alguns estudos 
apontem para uma maior prevalência de zumbido em mulheres [19, 94-96], não observamos diferenças estatisticamente significativas para gênero [23, 97, 98].

Tais observações, combinadas com a presença de EOAT e com limiares audiométricos normais, dão suporte à nossa hipótese de que a percepção auditiva fantasma experimentada pelos nossos sujeitos não esteja associada a um malfuncionamento periférico, como será discutido adiante.

\subsection{Comparação das percepções auditivas entre os experimentos}

Nos experimentos $\mathrm{H}$ e AV, a atenção seletiva estava voltada para a resolução da torre de Hanói e para a via visual, respectivamente. Assim, qualquer percepção auditiva nesses experimentos dependeu da atenção automática, enquanto que no experimento AA, ativou-se a atenção seletiva para a via auditiva. Embora o ruído de fundo da cabina tenha permanecido estável, o foco da atenção gerou diferenças significativas na percepção auditiva fantasma de nossos sujeitos.

Sabe-se que os processos cognitivos têm uma capacidade limitada [85]. Como a resolução da torre de Hanói demanda muito mais processos cognitivos (planejamento, memória operacional, inibição de comportamento e raciocínio indutivo) [99] que a tarefa de atenção visual, seria esperado que qualquer percepção auditiva fosse maior durante o experimento AV do que no $\mathrm{H}$, como foi realmente observado $(\mathrm{p}<0,001)$. No entanto, isso não exclui a possibilidade de que uma atividade neural relacionada ao zumbido estivesse sendo gerada durante o experimento $\mathrm{H}$, mas que a mesma apenas não estivesse recebendo atenção na maioria dos casos. O mesmo se aplica à diferença da ocorrência de percepções auditivas entre H e AA $(p<0,001)$ e entre AV e AA $(p<0,046)$. Isso também 
pode justificar o aumento significativo do número de percepções auditivas com AA, como será discutido adiante.

É conhecido o fato de que ativações "top-down", tais como atenção, expectativa, experiência prévia e memória, por exemplo, podem interferir no funcionamento de qualquer área do córtex cerebral [3, 100]. Dependendo da vontade do indivíduo ou da instrução recebida, essa ativação "top-down” modula a magnitude da atividade elétrica e a velocidade de processamento de informações, estejam elas acima ou abaixo de uma linha basal perceptual $[85,101]$. Como no experimento AA os sujeitos foram instruídos a focar sua atenção na via auditiva, o que sugeriria que algum som poderia ser realmente apresentado durante o experimento, a atenção seletiva e a expectativa auditiva, podem ter propiciado um ganho na sensibilidade auditiva desses sujeitos.

Entre nossos três experimentos, o único que pode ser comparado a estudos anteriores é o AA. Neste estudo, 68,2\% dos sujeitos relataram alguma percepção auditiva no experimento AA, um número muito inferior ao encontrado no estudo pioneiro de Heller e Bergman [7] (94\%) e ao de Del Bo et al. [9] na situação de silêncio com colocação das caixas de som (92\%), mas razoavelmente comparável ao de Tucker et al. [8] (64\%).

O alto índice de percepção de zumbido no estudo de Heller e Bergman [7] talvez esteja ligado à seleção dos participantes, pois foram considerados normo-ouvintes os indivíduos sem queixas e antecedentes otológicos e com boa saúde geral, porém sem comprovação audiométrica. Portanto, é possível que alguns deles tivessem algum grau de perda de audição em uma ou mais freqüências, favorecendo a percepção de um zumbido sub-clínico gerado pela disfunção coclear. Del Bo et al. [9] estudaram uma 
amostra que conhecidamente tinham limiares audiométricos melhores que $25 \mathrm{~dB}$ nas freqüências de 250 a $8000 \mathrm{~Hz}$, mas tiveram resultados compatíveis com os de Heller e Bergman [7]. Como já defendido anteriormente, consideramos que a ativação "topdown" influencia fortemente a percepção auditiva fantasma, e ao apresentarem previamente aos participantes do estudo uma lista de estímulos acústicos que poderiam ser percebidos os pesquisadores podem ter propiciado uma ativação "top-down" ainda mais intensa que a provocada pelo estudo de Heller e Bergman [7], que apenas pedia que os sujeitos anotassem num papel sons que pudessem escutar durante o experimento. Assim, acreditamos que a diferença dos nossos resultados com os de Del Bo et al. [9] sejam devido a uma ativação "top-down" mais robusta de seu experimento. Del Bo et al. [9] também investigaram o efeito da expectativa criada pela colocação de caixas de som dentro de uma câmara anecóica e observaram um aumento na frequiência de percepções auditivas fantasma, mas sem significado estatístico.

Um segundo ponto que pode ter favorecido o alto índice de "zumbido" da pesquisa de Heller e Bergman [7] refere-se à classificação das percepções auditivas, pois os autores consideraram como zumbido todos os sons percebidos pelos sujeitos, inclusive os sons habituais do próprio corpo (pulsação cardíaca e sons do sistema digestivo).

Portanto, concordamos com a conclusão de Tucker et al. [8] de que o aparecimento do zumbido em um ambiente silencioso em indivíduos saudáveis não seja um efeito tão universal quanto o sugerido por Heller e Bergman [7].

Não discordamos completamente com a hipótese de que um sistema auditivo normal possa produzir constantemente uma atividade neural [7, 8] ou emissões otoacústicas espontâneas [2] que, em ambientes extremamente silenciosos, possam ser 
interpretadas pelo cérebro como zumbido. A hipótese da percepção das emissões otoacústicas espontâneas não pode ser totalmente excluída [102] mas, embora estejam presentes em cerca de 70\% dos indivíduos com limiares audiométricos normais [103], a maioria das pessoas com emissões otoacústicas espontâneas nunca as escuta [14, 104]. Sendo assim, propomos uma hipótese alternativa. É possível que a privação sensorial breve e temporária tenha causado uma mudança também breve e temporária nos padrões de descarga neural do sistema auditivo central [105]. Essa hipótese é razoável, se levarmos em conta que dificilmente sujeitos com presença de emissão otoacústica transiente e audiometria normal teriam um zumbido de origem periférica. Portanto, é possível que as percepções auditivas fantasma experimentadas por nossos sujeitos tenham tido início em algum ponto do sistema auditivo central, e não na cóclea, o que é consistente com nossos achados e com teorias recentes a respeito da geração do zumbido $[10,43,45,78,106,107]$.

Como uma pessoa com audição normal é capaz de detectar uma vibração sonora de meio nanômetro (e a média tonal dos nossos participantes era em torno de 4 dBNA), também podemos supor que alguns indivíduos tenham conseguido detectar o movimento Browniano, que é de 1 a 2,7 nanômetros [61, 62]. Tal fato poderia levar à percepção de um chiado (moléculas de ar atingindo a membrana timpânica) ou favorecer, pela ressonância estocástica, a percepção de outros sinais elétricos em trânsito pela via auditiva.

Não podemos afirmar com certeza se as percepções auditivas nos indivíduos avaliados ocorreram por um possível desmascaramento de um zumbido central subaudível, por uma ativação estruturada do próprio SNAC em resposta à ativação de 
mecanismos "top-down", por mudanças nos padrões neurais do SNAC devido à privação auditiva temporária, por percepção do movimento Browniano ou mesmo pela combinação das hipóteses supracitadas.

\section{Vivências alucinatórias}

O maior número de percepções auditivas fantasma, assim como as diferenças qualitativas dessas percepções no experimento AA, foram resultados inesperados, mas que trouxeram a possibilidade de uma nova visão a respeito das vivências alucinatórias, como será visto adiante.

Uma das primeiras dificuldades foi classificar a grande diversidade de relatos de percepções auditivas (Anexo B), pois muitas não correspondem a descrições tipicamente associadas a zumbidos, como chiados, apitos, assobios, "hum", cigarras, cachoeira [17]. Então, agrupamos as percepções auditivas em grupos que melhor descreviam sua característica acústica: apito, chiado, “hum”, inseto, água corrente, música, vozes, outros e miscelânea (Gráficos 2, 3 e 4).

É interessante ressaltar que a grande maioria dos participantes acreditou estar mesmo ouvindo algum som apresentado pelas caixas de som dispostas dentro da cabina, o que caracteriza uma vivência alucinatória [46].

Se os participantes soubessem previamente do objetivo de pesquisar a presença de zumbido em ambiente silencioso, talvez tivéssemos obtido resultados diferentes. Por isso, informamos apenas sobre a intenção de estudar a atenção e em nenhum momento usamos a palavra zumbido. Muitos sujeitos tinham interesse em entender como havíamos controlado os sons ou queriam se certificar de que "ouviram certo", e as 
respostas eram dadas apenas após o término completo dos experimentos. Todos os sujeitos que tiveram percepções auditivas e que tinham a impressão de que realmente havia um som no ambiente ficaram muito surpresos e até embaraçados quando descobriam que na realidade nenhum som havia sido apresentado. $O$ embaraço era quebrado pela explicação de que essas percepções estavam se mostrando muito comuns entre indivíduos normais, e por isso estávamos estudando esse fenômeno.

Alguns relatos merecem uma descrição detalhada. O sujeito 19 escutou estalos, sibilo no ouvido esquerdo, grilo, tum-tum, relógio cuco e água escorrendo do lado direito. Ao fazer seu relato, ficou confuso porque o som do relógio cuco era o som do relógio cuco de seu pai e perguntou, desconfiado, como isso seria possível. O sujeito 38 escutou gotas de chuva, torneira aberta, vento uivando e pássaros piando. Ao descobrir que nenhum som havia sido apresentado, refletiu sobre o assunto e comentou que, para ele, o silêncio corresponde ao som da natureza, pois costuma fazer trilhas em matas e sempre considerou que estar em "paz" era estar no "silêncio" da mata e que, talvez, tivesse associado a idéia de silêncio da cabina com sua experiência de "silêncio". Já o sujeito 43 escutou o som de sua própria máquina de lavar roupa. No experimento AA (que foi seu segundo) achou que o som estava sendo apresentado dentro da cabina, e no experimento AV (terceiro) disse não ter certeza se o "som" estava em sua cabeça ou no ambiente. Ao descobrir que nenhum som havia sido apresentado, sua própria explicação foi a de que sempre procura pelo som da máquina de lavar roupa quando está em sua casa para saber se já precisa pendurar as roupas no varal.

Para lidar com o dinamismo e com as constantes novidades do ambiente, o cérebro precisou desenvolver capacidades sofisticadas de antecipação, como a expectativa e os 
mecanismos de controle baseados em predição [108]. Expectativas sensoriais aprendidas (“top-down”) são usadas para modular, antecipar e combinar a entrada da informação ("bottom-up") com o intuito de melhorar o seu desempenho na atividade a ser realizada [108]. Elas também ajudam no reconhecimento dos conjuntos de padrões sensoriais ("clusters") que têm prioridade para serem atendidas, ou seja, organizam o processamento da informação "bottom-up" e ajudam a pessoa a focar a atenção nos “clusters" salientes [109]. Assim, pode-se dizer que nossos comportamentos presentes são guiados pelas nossas expectativas e predições futuras, essas construídas por nossas experiências passadas [110]. Parece-nos bastante provável que os participantes tenham formulado hipóteses implícitas ou explícitas sobre os experimentos, o que pode ter facilitado a percepção de um zumbido sub-audível ou ter favorecido a percepção de padrões neurais da via auditiva que fossem erroneamente identificados como "clusters" de padrões temporais, o que pode ter gerado uma vivência alucinatória [111].

Podemos supor ainda que tais vivências alucinatórias estejam relacionadas à liberação de memórias auditivas. As representações perceptuais auditivas de um dado estímulo são armazenadas por dois sub-sistemas de memória corticais, um específico para o armazenamento da forma e estrutura de informações puramente acústicas e outro para representações fonológicas. Ambos são separados do sistema hipocampal, responsável pelo resgate da memória explícita, esta dedicada à representação semântica ou a formas de representação associativas [112, 113]. Todos os níveis talâmicos e corticais de processamento sensorial estão sujeitos a influências "top-down" [100]. Entretanto, mesmo que as expectativas “top-down" possam sensibilizar o processamento da informação aferente, geralmente não são suficientes isoladamente para causar uma 
ativação supra-liminar das células-alvo, pois a interação entre múltiplas áreas corticais e sua modulação por circuitos intrínsecos de retro-alimentação impede a criação de alucinações [100].

Consideramos que a expectativa, aliada à ativação de memórias auditivas relativas a experiências de "silêncio" tenham facilitado uma situação de imagética nãointencional, o que sabidamente ativa o córtex auditivo $[2,4,5]$ e que poderia, nas nossas condições experimentais, ter favorecido a geração de percepções auditivas fantasma.

Consideramos a possibilidade de que a atenção auditiva, somada à expectativa, à antecipação e ao ambiente extremamente silencioso (com entrada auditiva mínima) tenham provocado uma ativação tal do córtex auditivo que possa ter provocado a liberação de representações perceptuais auditivas. Isso poderia explicar algumas vivências alucinatórias, como as observadas nos participantes 19, 38 e 43.

Em nosso experimento a ativação endógena do sistema nervoso central não competiu com a ativação exógena, já que no silêncio esta é quase inexistente. Portanto, pode ter ocorrido uma ativação do córtex auditivo similar à evidenciada por Hunter et al. [1] e por Voisin et al. [3], o que corroboraria a teoria de que o funcionamento normal do cérebro já forneceria em si mesmo um substrato para as alucinações auditivas [1]. A gravação de potenciais eletrofisiológicos durante os experimentos talvez pudesse ter acrescentado dados interessantes sobre essa questão.

\section{Comentários finais}

Nossos achados sustentam a idéia de que a atenção é um componente fundamental na percepção do zumbido e de outras percepções auditivas fantasmas [38, 44], mesmo 
em se tratando de sujeitos sem queixa de zumbido. A conseqüência mais direta de nossos resultados provavelmente será sentida na abordagem terapêutica do paciente com zumbido.

Hoje, há um consenso de que pacientes com zumbido clinicamente significativos devam receber orientações acerca do funcionamento da via auditiva, do zumbido e das causas do incômodo com o sintoma e fazer uso de enriquecimento para reduzir a relação sinal-ruído entre o zumbido e o ambiente silencioso [39-41, 45], enquanto alguns autores defendem também o uso da terapia cognitiva para esses pacientes [38, 45, 70, 114]. Acreditamos que as orientações aos pacientes incomodados com o zumbido devam incluir esclarecimentos a respeito do papel da atenção na percepção do zumbido. É provável ainda que os mesmos se beneficiem de estratégias de controle do seu foco de atenção. Pesquisas futuras poderão avaliar possíveis diferenças na eficácia terapêutica com a adoção das medidas sugeridas.

Alguns questionamentos deixados por nosso estudo talvez possam ser respondidas por um estudo longitudinal. Os participantes que tiveram percepções típicas de zumbido nos experimentos terão mais chances de ter zumbido e/ou desenvolver perdas auditivas do que os que não tiveram percepções auditivas? Aqueles que tiveram alguma percepção auditiva no experimento $\mathrm{H}$, ou seja, mesmo com a atenção voltada para uma atividade que exigia esforço cognitivo, terão mais chances de se incomodarem com o zumbido do que os que só tiveram percepção auditiva fantasma com ativação da atenção auditiva? Os indivíduos que tiveram vivências alucinatórias são mais propensos a terem alucinose ou pseudo-alucinação? Embora nosso plano de pesquisa inicial não tenha previsto um acompanhamento longitudinal dos participantes, pretendemos contatá-los 
sistematicamente (em que espaço de tempo? a cada ano? a cada dois anos?) para tentarmos responder as questões aqui apresentadas.

Outras pesquisas que testem paradigmas experimentais nos quais indivíduos sem zumbido sejam instruídos a realizarem tarefas com e sem atenção auditiva em um ambiente silencioso controlado, mas com gravação de potenciais eletrofisiológicos relacionados ao zumbido, poderão acrescentar entendimento sobre os mecanismos de geração e percepção do sintoma.

Finalmente, é interessante notarmos que, às vezes, alguns estudos são tão marcantes que passam longos períodos sem serem questionados e sem que possíveis vieses sejam analisados, como foi o caso do trabalho de Heller e Bergman [7]. Nosso estudo exemplifica como a adoção de uma perspectiva diferente para uma mesma questão favorece o avanço da ciência. 


\section{Conclusões}

O silêncio, assim como a atenção auditiva, tem forte influência na percepção auditiva fantasma em indivíduos com limiares auditivos normais e sem zumbido.

A freqüência da percepção auditiva fantasma no silêncio com atenção seletiva para a via auditiva foi de $68,2 \%$. Com o desvio da atenção da via auditiva, esse índice cai para 45,5\% (atenção seletiva visual) e para 19,7\% (atenção para planejamento e solução de problemas).

Não há correlações significativas entre a percepção auditiva fantasma e as variáveis gênero, idade, nível de escolaridade, tontura prévia, hipertensão arterial e exposição prévia a níveis elevados de pressão sonora. 


\section{Anexo A}

\section{Formulário para coleta de dados}

Nome:

Idade: Sexo: $\mathrm{M} \mathrm{F}$

$\mathrm{N}^{\mathrm{o}}$ Id:

Profissão: 1200

Escolaridade

( ) $1^{\circ}$ grau incompleto ( ) grau universitário incompleto

( ) $1^{\circ}$ grau completo ( ) grau universitário completo

( ) $2^{\circ}$ grau incompleto ( ) pós-graduação universitária

( ) $2^{\circ}$ grau completo

Fatores de exposição

( ) ruído ocupacional

( ) ruído no lazer

( ) explosões

Alterações de saúde geral:

Medicamentos atuais:

( ) zumbido ( ) vozes ( ) música ( ) vertigem

Limiares audiométricos por via aérea

\begin{tabular}{|l|l|l|l|l|l|l|l|l|}
\hline & 250 & 500 & 1000 & 2000 & 3000 & 4000 & 6000 & $8000 \mathrm{~Hz}$ \\
\hline O.D. & & & & & & & & \\
\hline O.E. & & & & & & & & \\
\hline
\end{tabular}

EOAT

\begin{tabular}{|l|l|l|}
\hline & passa & falha \\
\hline O.D. & & \\
\hline O.E. & & \\
\hline
\end{tabular}

\begin{tabular}{|c|l|l|}
\hline Experimento & Percepção auditiva & Percepção visual \\
\hline H & & \\
\hline A & & \\
\hline V & & \\
\hline
\end{tabular}




\section{Anexo B}

Descrições ipsis literis das percepções auditivas nos experimentos Hanói, atenção visual e atenção auditiva e ocorrência de percepção visual $(*)$ de cada sujeito

\begin{tabular}{|c|c|c|c|}
\hline \multirow[t]{2}{*}{$\mathrm{N}^{\mathrm{o}} \mathrm{ID}$} & \multicolumn{3}{|c|}{ Descrição da percepção auditiva } \\
\hline & Hanói & atenção visual & atenção auditiva \\
\hline 1 & --- & som de ralar milho do lado direito & $\begin{array}{l}\text { som de ralar milho e de liquidificador } \\
\text { do lado direito }\end{array}$ \\
\hline 2 & $---*$ & furadeira do lado esquerdo* & furadeira do lado esquerdo* \\
\hline 3 & --- & --- & passos \\
\hline 4 & --- & som de mata & $\begin{array}{l}\text { som de mata, mola ou corda de } \\
\text { instrumento musical, avião ou trovão }\end{array}$ \\
\hline 5 & --- & --- & vozes e barulho \\
\hline 6 & --- & --- & pessoas conversando fraquinho \\
\hline 7 & --- & --- & --- \\
\hline 8 & --- & --- & --- \\
\hline 9 & --- & --- & --- \\
\hline 10 & --- & --- & papéis sendo arrumados e trovão \\
\hline 11 & --- & --- & $\begin{array}{l}\text { água distante constante e mosquinha } \\
\text { no ouvido esquerdo }\end{array}$ \\
\hline 12 & $---*$ & ruído fraquinho* & $\begin{array}{l}\text { folhas de papel sendo arrumadas ou } \\
\text { folhas de livros sendo viradas }\end{array}$ \\
\hline 13 & --- & --- & $\begin{array}{l}\text { som de alguém mexendo em folhas e } \\
\text { passos }\end{array}$ \\
\hline 14 & --- & --- & --- \\
\hline 15 & --- & --- & --- \\
\hline 16 & --- & --- & --- \\
\hline 17 & --- & --- & --- \\
\hline 18 & $\begin{array}{l}\text { zumbido (apito) no } \\
\text { ouvido esquerdo }\end{array}$ & zumbido (apito) no ouvido esquerdo & $\begin{array}{l}\text { zumbido (apito) no ouvido esquerdo } \\
\text { e cachorro latindo }\end{array}$ \\
\hline 19 & som grave suave & som grave suave & $\begin{array}{l}\text { estalos, sibilo no ouvido esquerdo, } \\
\text { grilo, tum-tum, relógio cuco, água } \\
\text { escorrendo do lado direito. }\end{array}$ \\
\hline 20 & --- & $\begin{array}{l}\text { som grave, como de caixa de som } \\
\text { ligada }\end{array}$ & $\begin{array}{l}\text { som grave, como de caixa de som } \\
\text { ligada }\end{array}$ \\
\hline
\end{tabular}




\begin{tabular}{|c|c|c|c|}
\hline $\mathrm{N}^{\mathrm{o}} \mathrm{ID}$ & Hanói & atenção visual & atenção auditiva \\
\hline 21 & abrir ou fechar de porta & $\begin{array}{l}\text { 'hum' em ouvido direito e } \\
\text { encanamento ou porta de correr }\end{array}$ & $\begin{array}{l}\text { buzinas, encanamento, tum-tum, } \\
\text { estalos, "hum" no ouvido direito e } \\
\text { sensação física do ouvido direito }\end{array}$ \\
\hline 22 & --- & --- & $\begin{array}{l}\text { motor passageiro lado direito e apito } \\
\text { agudo e fraquinho atrás da cabeça }\end{array}$ \\
\hline 23 & $\begin{array}{l}\text { cigarra intermitente em } \\
\text { ouvido direito }\end{array}$ & --- & --- \\
\hline 24 & --- & --- & --- \\
\hline 25 & --- & chuva bem fraca* & $\begin{array}{l}\text { som do vazio constante e som } \\
\text { metálico que vinha e ia embora, fraco } \\
\text { do lado direito }\end{array}$ \\
\hline 26 & --- & barulhinho de água lado direito & $\begin{array}{l}\text { ruído fraco e água de calha ou chuva } \\
\text { fraquinha do lado direito* }\end{array}$ \\
\hline 27 & --- & --- & $\begin{array}{l}\text { estalidos ou barulho de salto de } \\
\text { sapato }\end{array}$ \\
\hline 28 & --- & --- & --- \\
\hline 29 & $\begin{array}{l}\text { "hum" contínuo do lado } \\
\text { esquerdo }\end{array}$ & "hum" contínuo & "hum" que vinha e ia embora \\
\hline 30 & & & alguma coisa raspando fraquinho \\
\hline 31 & 28 & --- & --- \\
\hline 32 & "hum" & "hum" & $\begin{array}{l}\text { "hum", barulho do estômago, porta } \\
\text { batendo ou passos }\end{array}$ \\
\hline 33 & $\begin{array}{l}\text { "hum" fraco, pressão nos } \\
\text { ouvidos, eco de som de } \\
\text { encaixe de partes da } \\
\text { cabina }\end{array}$ & $\begin{array}{l}\text { "hum" ou chiadinho vindo das caixas } \\
\text { de som* }\end{array}$ & $\begin{array}{l}\text { "hum" dos dois lados, mais forte do } \\
\text { lado direito e dois passos }\end{array}$ \\
\hline 34 & $\begin{array}{ll}-- \\
\end{array}$ & chiado & chiado e barulho do estômago \\
\hline 35 & $\begin{array}{ll}-- \\
\end{array}$ & inseto comendo papelão* & $\begin{array}{l}\text { sapo coachando duas vezes, bebê } \\
\text { chorando, som madeira da cabina se } \\
\text { expandindo com calor }\end{array}$ \\
\hline 36 & --- & --- & --- \\
\hline 37 & --- & --- & $\begin{array}{l}\text { passos, saltos no chão e apito fino do } \\
\text { lado direito }\end{array}$ \\
\hline
\end{tabular}




\begin{tabular}{|c|c|c|c|}
\hline $\mathrm{N}^{\mathrm{o}}$ ID & Hanói & atenção visual & atenção auditiva \\
\hline 38 & --- & grilo em ouvido esquerdo & $\begin{array}{l}\text { gotas de chuva, torneira aberta, vento } \\
\text { uivando, pássaros piando, tudo } \\
\text { fraquinho }\end{array}$ \\
\hline 39 & reator de lâmpada & reator de lâmpada & som de reator de lâmpada \\
\hline 40 & --- & --- & $\operatorname{tim} . . .$. \\
\hline 41 & --- & --- & sininho, água correndo e cachoeira \\
\hline 42 & $\begin{array}{l}\text { "hum" e estalidos de } \\
\text { cronômetro }\end{array}$ & --- & "hum" \\
\hline 43 & --- & máquina de lavar roupa & máquina de lavar roupa de sua casa \\
\hline 44 & --- & $\begin{array}{l}\text { zunido ou cigarra muito longe no } \\
\text { lado esquerdo* }\end{array}$ & $\begin{array}{l}\text { "hum" ou inseto batendo asas do lado } \\
\text { direito e rede elétrica do lado } \\
\text { esquerdo }\end{array}$ \\
\hline 45 & --- & $\begin{array}{l}\text { apito em ouvido direito e cigarra em } \\
\text { ouvido esquerdo }\end{array}$ & chiado e cigarra no ouvido direito \\
\hline 46 & --- & $---*$ & --- \\
\hline 47 & --- & mosquitinhos voando & $\begin{array}{l}\text { mosquitinhos voando ou reator de } \\
\text { lâmpada }\end{array}$ \\
\hline 48 & --- & --- & --- \\
\hline 49 & --- & --- & --- \\
\hline 50 & --- & --- & --- \\
\hline 51 & --- & --- & --- \\
\hline 52 & hélice e um pingo d'água & $\begin{array}{l}\text { um bip, um pingo d'água e hélice } \\
\text { girando em ouvido direito }\end{array}$ & alguma coisa raspando* \\
\hline 53 & --- & --- & zumbido passageiro \\
\hline 54 & --- & --- & motor distante do lado esquerdo \\
\hline 55 & --- & $---*$ & música fraquinha do lado esquerdo \\
\hline 58 & --- & $\begin{array}{l}---* \\
---\end{array}$ & $\begin{array}{l}\text { batidinhas fracas, como de } \\
\text { microfone, por pouco tempo } \\
\text {--- }\end{array}$ \\
\hline 59 & --- & "hum" intermitente dos dois lados & $\begin{array}{l}\text { "hum" intermitente dos dois lados, } \\
\text { mais forte do lado direito }\end{array}$ \\
\hline 60 & SSS... & SSS... & Sss... \\
\hline 61 & --- & $---*$ & --- \\
\hline
\end{tabular}




\begin{tabular}{|c|c|c|c|}
\hline $\mathrm{N}^{\mathrm{o}}$ ID & Hanói & atenção visual & atenção auditiva \\
\hline 62 & --- & $\begin{array}{l}\text { um barulhinho igual ao da máquina } \\
\text { (audio) diferente em cada ouvido }\end{array}$ & $\begin{array}{l}\text { barulho igual ao da máquina } \\
\text { (audiômetro) diferente em cada } \\
\text { ouvido }\end{array}$ \\
\hline 63 & --- & chiadinho em ouvido direito, oscilava & $\begin{array}{l}\text { chiadinho no começo e duas } \\
\text { batidinhas de pé fora da cabine }\end{array}$ \\
\hline 64 & motorzinho* & ventilador & \\
\hline 65 & música fraquinha & música & música e batidinhas na madeira \\
\hline 66 & --- & --- & --- \\
\hline
\end{tabular}




\section{Referências}

[1] Hunter MD, Eickhoff SB, Miller TW, Farrow TF, Wilkinson ID, Woodruff PW. Neural activity in speech-sensitive auditory cortex during silence. Proc Natl Acad Sci USA 2006;103:189-94.

[2] King AJ. Auditory Neuroscience: Activating the Cortex without Sound. Current Biology. 2006;16(11):R410-R1.

[3] Voisin J, Bidet-Caulet A, Bertrand O, Fonlupt P. Listening in Silence Activates Auditory Areas: A Functional Magnetic Resonance Imaging Study. J Neurosci. 2006;26(1):273-8.

[4] Hoshiyama M, Gunji A, Kakigi R. Hearing the sound of silence: a magnetoencephalographic study. Neuroreport. 2001;12(6):1097-102.

[5] Bunzeck N, Wuestenberg T, Lutz K, Heinze H, Jancke L. Scanning silence: Mental imagery of complex sounds. NeuroImage 2005;26:1119-27. 
[6] Ferreira ABH. Aurélio. Dicionário Aurélio básico da língua portuguesa. Rio de Janeiro: Editora Nova Fronteira 1988.

[7] Heller MF, Bergman M. Tinnitus aurium normally hearing persons. Ann Otol. $1953 ; 62: 73-83$.

[8] Tucker DA, Phillips SL, Ruth RA, Clayton WA, Royster E, Todd AD. The effect of silence on tinnitus perception. Otolaryngol Head Neck Surg. 2005;132(1):20-4.

[9] Del Bo L, Langguth B, Costanzo S, Forti S, Mauro D, Ugazio G, et al. Tinnitus aurium in normally hearing persons: 54 years later: preliminary results. Advances in Tinnitus Assessment, Treatment and Neuroscience Basis Conference

Grand Island, New York 2007.

[10] Eggermont JJ. Central tinnitus. Auris Nasus Larynx 2003;30:S7-S12.

[11] Nam E. Is it necessary to differentiate tinnitus from auditory hallucination in schizophrenic patients? J Laryngol Otol. 2005(119):352-5.

[12] Evers S, Ellger T. The clinical spectrum of musical hallucinations. J Neurol Sci 2004;227:55-65.

[13] Johns LCH, D.; Kuipers, E. A comparison of auditory hallucinations in a psychiatric and non-psychiatric group. Br J Clinic Psychol. 2002;41:81-6.

[14] Levine RA, Abel M, Cheng H. CNS somatosensory-auditory interactions elicit or modulate tinnitus. Exp Brain Res. 2003;153:643-8.

[15] Sanchez TG, Guerra GCY, Lorenzi MC, Brandão AL, Bento RF. The influence of voluntary muscle contractions upon the onset and modulation of tinnitus. Audiol Neuro-Otol. 2002;76(6):370-5. 
[16] Ahmad N, Seidman M. Tinnitus in the Older Adult: Epidemiology, Pathophysiology and Treatment Options. Drugs Aging 2004;21(5):297-305.

[17] Dobie RA. Overview: Suffering from Tinnitus. In: Snow JB, ed. Tinnitus: Theory and Management. Hamilton: BC Decker 2004:1-7.

[18] Georgiewa P, Klapp BF, Fischer F, Reisshauer A, Juckel G, Frommer J, et al. An integrative model of developing tinnitus based on recent neurobiological findings. Med Hypotheses 2006;66:592-600.

[19] Sanchez TG, Bento RF, Miniti A, Câmara J. Zumbido: características e epidemiologia. Experiência do Hospital das Clínicas da Faculdade de Medicina da Universidade de São Paulo. Rev Bras Otorrinolaringol. 1997;63(3):229-35.

[20] Fukuda Y, Mota P, Mascardi D. Avaliação clínica de zumbidos: Resultados iniciais. Acta AWHO. 1990;9(3):99-104.

[21] Martins MC. Zumbido: um estudo de suas características e ocorrência em uma clínica otorrinolaringológica. São Paulo: Pontifícia Universidade Católica de São Paulo; 1991.

[22] Coelho CCB, Sanchez TG, Bento RF. Características do zumbido em pacientes atendidos em serviço de referência. Arq Fund Otorrinolaringol. 2004;8(10):216-24.

[23] Sanchez TG, Mak MP, Pedalini MEB, Levy CPD, Bento RF. Evolução do zumbido e da audição em pacientes com audiometria tonal normal. Arq Int Otorrinolaringol. 2005;9(3):327-431.

[24] Howard J. Hoffman M, George W. Epidemiology of Tinnitus. In: Snow JB, ed. Tinnitus: Theory and Management. Hamilton: BC Decker 2004:16-42. 
[25] Howard J, Hoffman MA, George W. Epidemiology of Tinnitus. In: Snow JB, ed. Tinnitus: Theory and Management. Hamilton: BC Decker 2004:16-42.

[26] Jastreboff PJJ. Phantom auditory perception (tinnitus): mechanisms of generation and perception. Neurosci Res 1990;8:221-56.

[27] Wang J, Salvi RJ, Powers N. Plasticity of response properties of inferior colliculus neurons following acute cochlear damage. J Neurophysiol. 1996;75:171-84.

[28] Salvi RJ, Wang J, Powers N. Rapid functional reorganization in the inferior colliculus and cochlear nucleus after acute cochlear damage. In: Salvi RJ, Henderson D, Fiorino F, Colletti V, eds. Auditory Plasticity and Regeneration. New York: Thieme Medical Publishers 1996:275-96.

[29] Zirpel L, Lachica EA, Rubel EW. Afferent regulations of neurons in the avian cochlear nucleus: intracellular mechanisms and signal transduction pathways. In: Berlin C, ed. Neurotransmission and hearing loss - Basic science, diagnosos and management. San Diego: Singular Publing Group 1997:77-89.

[30] Willot JF. Physiological plasticity in the auditory system and its possible relevance to hearing aid use, deprivation and acclimatization. Ear Hear. 1996;17:66-77.

[31] Rajan R. Plasticity and inhibition in the receptive field of primary auditory cortical neurons after limited receptor organ damage. Cereb Cortex. 2001;11:171-82.

[32] Salvi R, Wang J, Ding D. Auditory plasticity and hyperactivity following cochlear damage. Hearing Res. 2000;147:261-76.

[33] Tucci DL, Cant NB, Durham D. Efects of conductive hearing loss on gerbil central auditory system activity in silence. Hearing Res. 2001;155:124-32. 
[34] Brozoski TJ, Bauer CA, Caspary DM. Elevated Fusiform Cell Activity in the Dorsal Cochlear Nucleus of Chinchillas with Psychophysical Evidence of Tinnitus. J Neurosci. 2002;22(6):2383-90.

[35] Cacace AT. Expanding the biological basis of tinnitus: crossmodal origins and the role of neuroplasticity. Hear Res. 2003;175:112-32.

[36] Davies A, Rafie EA. Epidemiology of tinnitus. In: Tyler RS, ed. Tinnitus handbook. San Diego: Singular. Thomson Learning. 2000:1-23.

[37] Hallam RS, Rachman S, Hinchcliffe R. Psycological aspects of tinnitus. In: Rachman S, ed. Contributions to medical psycology. Oxford: Pergamon Press 1984:3153.

[38] Andersson G. Psychological aspects of tinnitus and the application of cognitivebehavioral therapy. Clin Physiol Review 2002;22:977-90.

[39] Jastreboff PJ, Hazell JP. Neurophysiological approach to tinnitus: clinical implications. Br J Audiol. 1993;27(1):7-17.

[40] Jastreboff PJ, Jastreboff MM. Tinnitus Retraining Therapy for patients with tinnitus and decreased sound tolerance. Otolaryngol Clin North Am. 2003;36(2):321-5.

[41] Knobel KAB, Branco-Barreiro FCA, Sanchez TG. Terapia de Habituação do Zumbido. In: Samelli AG, ed. Zumbido: avaliação, diagnóstico e reabilitação (abordagens atuais). São Paulo: Lovise 2004:95-102.

[42] Jacobson GP, Calder JA, Newman CW, Peterson EL, Wharton JA, Ahmad BK. Eletrophysiological indices of selective auditory attention in subjects with and without tinnitus. Hearing Res. 1996;97:66-74. 
[43] Lockwood AH, Salvi RJ, Coad ML, Towsley ML, Wack DS, Murphy BW. The functional neuroanatomy of tinnitus: evidence for limbic system links and neural plasticity. Neurology. 1998;50:114-20.

[44] Mirz F, Pedersen CB, Ishizu K, Johannsen P, Ovesen T, Stödkilde-Jörgensen H, et al. Positron emission tomography of cortical centers of tinnitus. Hearing Res. 1999;134:133-44.

[45] Baguley DM. What progress have we made with tinnitus? Acta Oto-Laryngol. 2006;126:4-8.

[46] Cheniaux E. Psicopatologia descritiva: existe uma linguagem comum? Rev Bras Psiquiatr. 2005;27(2):157-62.

[47] American Association of Psyquiatry. Diagnostic and Statistical Manual of Mental Disorders. Fourth Edition ed. Washington D. C.: American Psychiatric Association 1994.

[48] Ballone GJ. Psiqweb. 2007 [cited 28/02/2007]; Available from: http://www.psiqweb.med.br/gloss/

[49] Baldo MVV, Haddad H. Ilusões: o olho mágico da percepção. Rev Bras Psiquiatr. 2003;25(Supl II):6-11.

[50] Fukunishi I, Horikawa N, Onai H. Prevalence rate of musical hallucinations in a general hospital setting. . Psychosomatics. 1998;39:175.

[51] Lam LCW, Leung SF, Chow LY. Functional experiential hallucinosis after radiotherapy for nasopharyngeal carcinoma. J Neurol Neurosurg Psychiatry. 1998;64:259-61. 
[52] Cole MG, Dowson L, Dendukuri N, Belzile ET. The prevalence and phenomenology of auditory hallucinations among elderly subjects attending an audiology clinic. Int J Geriatr Psychiatry. 2002;17:444-52.

[53] Lennox BR, Bert S, Park G, Jones PB, Morris PG. Spatial and temporal mapping of neural activity associated with auditory hallucinations. Lancet. 1999;353(20 Feb):644. [54] Shergill SS, Brammer MJ, Williams SC, Murray RM, McGuire PK. Mapping auditory hallucinations in schizophrenia using functional magnetic resonance imaging. Arch Gen Psychiatry. 2000;57(11):1033-8.

[55] Shergill SS, Bullmore ET, Brammer MJ, Williams SC, Murray RM, McGuire PK. A functional study of auditory verbal imagery. Psychol Med. 2001;31(2):241- 53.

[56] Jancke L, Shah NJ. Hearing syllables by seeing visual stimuli. Eur J Neurosci. 2004;19(9):2603-8.

[57] Bentall RP. The illusion of reality: A review and integration of psychological research on hallucinations. Psychol Bull. 1990;107:82-95.

[58] Griffiths TD, Warren JD, Scott SK, Nelken I, King AJ. Cortical processing of complex sound: a way forward? Trends Neurosci. 2004;27(4):181-5.

[59] Bialek W. Physical limits to sensation and perception. Ann Rev Biophys Chem. 1987;16(45):455-78.

[60] Lawson JL, Uhlenbeck GE. Threshold signals. New York: McGraw-Hill 1950.

[61] Jaramillo F, Wiesenfeld K. Mechanoelectrical transduction assisted by Brownian motion: a role for noise in the auditory system. Nature Neurosci. 1998;1(5):384-8.

[62] Zeng F, Martino KM, Linthicun FH, Soli SD. Auditory perception in vestibular neurectomy subjects. Hearing Res. 2000;142:102-12. 
[63] Engler CW. Treatment of tinnitus. JAMA. 1957;163(8):615-7.

[64] Graham JT, Newby HA. Acoustical characteristics of tinnitus: an analysis. Arch Otolaryngol. 1962;75(2):162-7.

[65] Atherley GR, Hempstoc TI, Noble WG. Study of tinnitus induced temporarily to noise. J Acoust Soc Am. 1968;44(6):1503-6.

[66] Lummis RCG, N. Exploratory studies of zwickers negative afterimage in hearing. J Soc Acoust Am. 1972;51(1):1930-44.

[67] Vernon J, Schleuning A. Tinnitus: new management. Laryngoscope. 1978;88(3):413-9.

[68] Hazell JWP. Tinnitus. British J Hosp Med. 1979;22(2):468-71.

[69] Shulman A. Subjective idiopatic tinnitus: a reveiw. J Laryngol Otol. 1981;suppl. $4: 1-9$

[70] Jakes SC, Hallam RS, Rachman S, Hinchcliffe R. The effects of reassurance, relaxation training and distraction on chronic tinnitus sufferers. Advances in Behaviour Research and Therapy. 1986;24(5):497-507.

[71] Coles RRA, Hallam RS. Tinnitus and its management. $\mathrm{Br}$ Med Bull. 1987;43(4):983-98.

[72] Borton TE, Clark SR. Electromyographic biofeedback for treatment of tinnitus. Am J Otology. 1988;9(1):23-30.

[73] Jakes S. Otological Symptoms and emotion: a reveiw of the literature. Advances in behaviour research and therapy. 1988;10(2):53-103.

[74] Oliveira CA, Schunknecht HF, Glynn RJ. In search of cochlear morphological correlates for tinnitus. Arch Otolaryngol Head Neck Surg. 1990;116(8):937-9. 
[75] Hallberg LRM, Erlandsson SI. Tinnitus characteristics in tinnitus complainers and noncomplainers. British J Audiol. 1993;27(1):19-27.

[76] Holgers KM, Erlandsson SI, Barrenas ML. Predictive factors for the severity of tinnitus. Audiology. 2000;39(5):284-300.

[77] Zoger S, Svedlund J, Holgers KM. Psychiatric disorders in tinnitus patients without severe hearing impairment: 24 month follow-up of patients at an audiological clinic. Audiology. 2001;40(3):133-40.

[78] Attias J, Reshef I, Shemesh Z, Salomon G. Support for the central theory of tinnitus generation: a military epidemiological study. Int J Audiol. 2002;41(5):301-7.

[79] Baguley DM. Mechanisms of tinnitus. Br Med Bulletin. 2002;62:195-202.

[80] Lockwood AH, Salvi RJ, Burkard RF. Current concepts: Tinnitus. NEJM. 2002;347(19):904-10.

[81] Helene AF, Xavier GF. A construção da atenção a partir da memória. Rev Bras Psiquiatr. 2003;25(Supl II):12-20.

[82] Hughes RWJ, D.M. Indispensable Benefits and Unavoidable Costs of Unattended Sound for Cognitive Functioning. Noise \& Health. 2003;6(Oct-Dec):14.

[83] Cuny C, Norena A, Massioui FE, Chéry-Croze S. Reduced attencion shift in response to auditory changes in subjects with tinnitus. Audiol Neurootol. 2004;9:294302.

[84] Hughes RWJ, D.M. . Indispensable Benefits and Unavoidable Costs of Unattended Sound for Cognitive Functioning. Noise \& Health. 2003;6:63-76. 

whhancement and suppression of the magnitude and speed of neuro activity. J Cognitive Neurosciense. 2005;17(3):505-17.

[86] Pessoa L, Kastner S, Ungerleider LG. Neuroimaging studies of attention: from modulation of sensory processing to top-down control. J Neurosci. 2003;23:3990-8.

[87] Mitchell TV, Morey RA, Inan S, Belger A. Functional magnetic resonance imaging measure of automatic and controlled auditory processing. Neuroreport. 2005;16(5):457-61.

[88] Baldeweg T. Repetition effects to sounds: evidence for predictive coding in the auditory system. Trends Cognitive Sciences. 2006;10(3):93-5.

[89] Redondo MC, Lopes $\mathrm{F}^{o} \mathrm{OC}$. Testes básicos de avaliação auditiva. In: Lopes $\mathrm{F}^{\mathrm{o}}$ OC, ed. Tratado de fonoaudiologia. São Paulo: Ed. Roca 1997:83-108.

[90] Kemp DT, Ryan S, Bray P. A Guide to the Effective Use of Otoacoustic Emissions. Ear Hear. 1990;11(2):93-105.

[91] Barboni M, Geraldi AT, Goffi-Gomez MVS, Schultz C, Liberman PHP. Variação Teste-reteste da Amplitude das Emissões Otoacústicas Transientes Evocadas em Indivíduos Normais. Arq Int Otorrinolaringol. 2006;10(2):119-24.

[92] Kemp DT. Exploring cochlear status with otoacoustic emissions: the potential for new clinical applications. In: Robinette MS, Glattke TJ, eds. Otoacoustic Emissions Clinical Applications. 2a edição ed. New York: Thieme 2002:1-47.

[93] Lopes Fo O; Carlos RC. Emissões Otoacústicas. In: Lopes Fo O, ed. Tratado de Fonoaudiologia $2^{\mathrm{a}}$ ed. Ribeirão Preto: Tecmedd 2005:207-22. 
[94] Nuttall AL, Meikle MB, Trune DR. Peripheral Processes Involved in Tinnitus. In: Snow JB, ed. Tinnitus: Theory and Management. Hamilton: BC Decker 2004:52-68. [95] Davis AC. The prevalence of hearing impairment and reported hearing disability among adults in Great Britain. Int J Epid. 1989(18):911-7.

[96] Abutan BB, Hoes AW, Van Dalsen CL, Verschuure J, Prins A. Prevalence of Hearing Impairment and Hearing Complaints in Older Adults: A Study in General Practice Family Practice. 1993;10(4):391-5.

[97] Kuttila S, Kuttila M, Bell Y, Alanen P, Suonpää J. Recurrent tinnitus and associated ear symptoms in adults. Int J Audiol. 2005;44(3):164 - 70.

[98] Pilgramm M, Rychlick R, Lebisch H, Siedentop H, Goebel G, al. e. Tinnitus in Federal Republic of Germany: A representative epidemiologic study. Proceedings of the sixth International Tinnitus Seminar; 1999; Cambridge, UK: Hazell J, (ed.); 1999. p. 647.

[99] Welsh MC, Huizinga M. Tower of Hanoi disk-transfer task: Influences of strategy knowledge and learning on performance. Learning and Individual Differences. 2005 May;15:283-98.

[100] Gilbert CD, Sigman M. Brain States: Top-Down Influences in Sensory Processing. Neuron. 2007;54:677-96.

[101] Chawla D, Rees G, Friston KJ. The physiological basis of attentional modulation in extrastriate visual areas. Nature Neurosci. 1999;2:671-6.

[102] Prasher D, Ceranic B, Sulkowsky W, Guzek W. Objective evidence for tinnitus from spontaneous emission variability Noise \& Health. 2001;3(12):61-73. 
[103] Bright KE. Spontaneous Otoacoustic Emissions. In: Robinette MSG, T.J., ed. Otoacoustic Emissions: Clinical Applications. 2nd ed. New York: Thieme Medical Publishers 2002:74-94.

[104] Wilson JP. Otoacoustic emissions and tinnitus Scand Audiol (Suppl). 1986;25:109-19.

[105] Knobel KAB, Sanchez TG. Privação Auditiva, Circuitos Inibitórios e Plasticidade: Implicações na Compreensão do Zumbido e da Hiperacusia. Arq Otorrinolaringol. 2005;9(4):306-12.

[106] Kaltenbach JA, Zhang J, Zacharek MA. Neural Correlates of Tinnitus. In: Snow JB, ed. Epidemiology of Tinnitus. Hamilton: BC Decker 2004:141-61.

[107] Bauer CA. Mechanisms of tinnitus generation. Current Opinion in Otolaryngology \& Head and Neck Surgery. 2004;12:413-7.

[108] Stadler W, Klimesch W, Pouthas V, Ragot R. Differential effects of the stimulus sequence on CNV and P300. Brain Reseach. 2006;1123:157-67.

[109] Grossberg S. How hallucinations may arise from brain mechanisms of learning, attention, and volition. JINS 2000;6:583-92.

[110] Helene A, F.; Xavier GF. A construção da atenção a partir da memória. Rev Bras Psiquiatr. 2003;25(Supl II):12-20.

[111] Griffiths TD. Musical hallucinosis in acquired deafness: phenomenology and brain substrate. Brain. 2000;123:2065-76.

[112] Ratcliff R, Allbritton D, McKoon G. Bias in Auditory Priming. J Exp Psychol Learn Mem Cogn 1997;23(1):143-52. 
[113] Church BA, Schacter DL. Perceptual specificity of auditory priming: Implicit memory for voice intonation and fundamental frequency. J Exp Psychol Learn Mem Cogn 1994;20(3):521-33.

[114] Andersson G, Khakpoor YA, Lyttkens LY. Masking of tinnitus and mental activity. Clin Otolaryngol. 2002;27:270-4. 